\title{
Global stratospheric measurements of the isotopologues of methane from the Atmospheric Chemistry Experiment Fourier transform spectrometer
}

\author{
Eric M. Buzan ${ }^{1}$, Chris A. Beale ${ }^{2}$, Chris D. Boone ${ }^{3}$, and Peter F. Bernath ${ }^{1,3}$ \\ ${ }^{1}$ Department of Chemistry and Biochemistry, Old Dominion University, Norfolk, Virginia, USA \\ ${ }^{2}$ Department of Ocean, Earth, and Atmospheric Sciences, Old Dominion University, Norfolk, Virginia, USA \\ ${ }^{3}$ Department of Chemistry, University of Waterloo, Waterloo, Ontario, Canada
}

Correspondence to: Eric M. Buzan (ebuzan@ odu.edu)

Received: 11 August 2015 - Published in Atmos. Meas. Tech. Discuss.: 29 October 2015

Revised: 26 February 2016 - Accepted: 2 March 2016 - Published: 18 March 2016

\begin{abstract}
This paper presents an analysis of observations of methane and its two major isotopologues, $\mathrm{CH}_{3} \mathrm{D}$ and ${ }^{13} \mathrm{CH}_{4}$, from the Atmospheric Chemistry Experiment (ACE) satellite between 2004 and 2013. Additionally, atmospheric methane chemistry is modeled using the Whole Atmospheric Community Climate Model (WACCM). ACE retrievals of methane extend from $6 \mathrm{~km}$ for all isotopologues to $75 \mathrm{~km}$ for ${ }^{12} \mathrm{CH}_{4}, 35 \mathrm{~km}$ for $\mathrm{CH}_{3} \mathrm{D}$, and $50 \mathrm{~km}$ for ${ }^{13} \mathrm{CH}_{4}$. While total methane concentrations retrieved from ACE agree well with the model, values of $\delta \mathrm{D}-\mathrm{CH}_{4}$ and $\delta^{13} \mathrm{C}-\mathrm{CH}_{4}$ show a bias toward higher $\delta$ compared to the model and balloon-based measurements. Errors in spectroscopic constants used during the retrieval process are the primary source of this disagreement. Calibrating $\delta \mathrm{D}$ and $\delta^{13} \mathrm{C}$ from ACE using WACCM in the troposphere gives improved agreement in $\delta \mathrm{D}$ in the stratosphere with the balloon measurements, but values of $\delta^{13} \mathrm{C}$ still disagree. A model analysis of methane's atmospheric sinks is also performed.
\end{abstract}

\section{Introduction}

Methane is an important greenhouse gas, with a globalwarming potential of 72 over 20 years (Denman et al., 2007). In the troposphere, abundances of methane have increased since the Industrial Revolution, from mixing ratios of about $700 \mathrm{ppb}$ in the 1800 s to over $1700 \mathrm{ppb}$ by the $1990 \mathrm{~s}$ (Etheridge et al., 1998). From 1999 to 2006, methane levels remained stable, but have begun to increase again since
2007 (Terao et al., 2011). The mixing ratio of methane in the atmosphere is controlled by its sources and sinks. All sources of methane are from surface emissions, including wetlands (Bartlett and Harriss, 1993), ruminant livestock (Lassey, 2007), fossil fuel production (Kort et al., 2014), and biomass burning (Hao and Ward, 1993). Methane is primarily consumed by the $\mathrm{OH}$ radical in the troposphere but may also react with $\mathrm{Cl}$ and singlet $\mathrm{O}\left(\mathrm{O}^{1} \mathrm{D}\right)$ or be destroyed by photolysis higher in the atmosphere. With a global lifetime of about 9 years (Denman et al., 2007), methane is well mixed in the troposphere but decreases rapidly with altitude in the stratosphere. The distribution of methane is also affected by atmospheric circulation patterns. One major pattern is Brewer-Dobson circulation, in which equatorial air rises through the tropopause, travels poleward in the stratosphere, then descends back into the troposphere at high latitudes and returns to the equator (Remsberg, 2015).

Knowing the relative strengths of the different sources and sinks of methane is crucial for understanding its atmospheric behavior. As these sources and sinks are subject to isotopic fractionation, measurement of the common stable isotopologues of methane $\left({ }^{12} \mathrm{CH}_{4},{ }^{12} \mathrm{CH}_{3} \mathrm{D}\right.$, and $\left.{ }^{13} \mathrm{CH}_{4}\right)$ gives more information about the origin of methane present in the atmosphere. Abundances of heavy isotopologues are typically reported using delta notation, where (for the case of carbon13)

$\delta^{13} \mathrm{C}=\left(\frac{{ }^{13} \mathrm{C} /{ }^{12} \mathrm{C}}{{ }^{13} \mathrm{C}_{\mathrm{std}} /{ }^{12} \mathrm{C}_{\mathrm{std}}}-1\right) \times 1000 \%$. 
In this paper, $\delta \mathrm{D}$ will refer to the isotopologue $\mathrm{CH}_{3} \mathrm{D}$, and $\delta^{13} \mathrm{C}$ will refer to ${ }^{13} \mathrm{CH}_{4}$.

Different isotopologues of methane will react at different rates, a phenomenon known as the kinetic isotope effect (KIE). Because of this, the isotopic signature of methane in an air mass will change over time as methane is consumed. As is true of most molecules, the heavier isotopologues of methane react more slowly than unsubstituted methane, meaning $\delta \mathrm{D}$ and $\delta^{13} \mathrm{C}$ will increase as methane is consumed. KIEs are commonly reported as a ratio of rate constants: $k_{\mathrm{D}} / k_{\mathrm{H}}$ and $k_{12} / k_{13}$ for methane. The KIEs of methane with $\mathrm{OH}, \mathrm{O}\left({ }^{1} \mathrm{D}\right)$, and $\mathrm{Cl}$ at room temperature are listed in Table 2. Since each methane sink has a different KIE, the values of $\delta \mathrm{D}$ and $\delta^{13} \mathrm{C}$ can give some information about which species have reacted with methane.

As with several gases in the atmosphere, there is a strong inverse correlation between the total mixing ratio of methane and $\delta \mathrm{D}$ and $\delta^{13} \mathrm{C}$. This relation was first noted by Keeling (1958) in samples of $\mathrm{CO}_{2}$, so a plot of $\left[\mathrm{CH}_{4}\right]$ or $\left[\mathrm{CH}_{4}\right]^{-1}$ vs. $\delta$ is often called a "Keeling plot". This phenomenon has more recently been demonstrated by, e.g., Röckmann et al. (2011) for methane. Plotting $\left[\mathrm{CH}_{4}\right]^{-1}$ vs. $\delta$ of a time series of measurements results in a ellipse rather than a straight line due to seasonal variation in the sources and sinks of methane (Allan et al., 2001; Lassey et al., 2011).

Measuring methane and its isotopologues is most commonly done in the troposphere. One large ground-based sampling program is the Global Greenhouse Gas Reference Network, overseen by NOAA's Earth System Research Laboratory (Andrews et al., 2014). Sampling higher in the troposphere is frequently done by aircraft such as the CARIBIC program (Brenninkmeijer et al., 2007) or by balloon flights. In the upper stratosphere, measurements are far less common as only balloons can reach this height for sampling (Röckmann et al., 2011). An alternative to direct sampling at this altitude is satellite-based remote sensing. Some satellite instruments point toward nadir including GOSAT (Yokota et al., 2009), TES onboard the Aura satellite (Wecht et al., 2012), and IASI on MetOp (Xiong et al., 2013). Others observe the limb of the atmosphere including MIPAS (Payan et al., 2009) and HALOE (Park, 2004). A few, such as SCIAMACHY on ENVISAT (Schneising et al., 2009) and TES can look in either direction. However, these satellite measurements do not include the heavy isotopes of methane, and many of them have limited vertical sampling or only measure the total column density.

In this paper we present data on methane and its two heavy isotopologues from the Atmospheric Chemistry Experiment Fourier transform spectrometer (ACE-FTS). Additionally, we performed a model run with Whole Atmosphere Climate Community Model for comparison to the data from ACE.

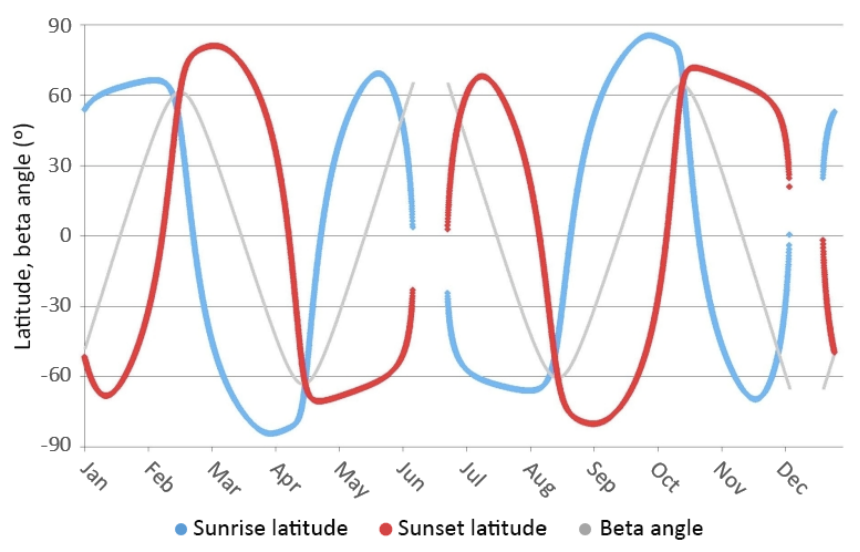

Figure 1. ACE measurement latitude for sunrise and sunset and beta angle as a function of time of year. For a brief time around each solstice ACE is unable to make measurements due to the position of its orbit.

\section{Methods}

The ACE-FTS is an infrared spectrometer on board the Canadian satellite SCISAT. SCISAT was launched in 2003 and is still currently active. The satellite orbits the Earth at an inclination of $74^{\circ}$ and at a height of $650 \mathrm{~km}$. It makes measurements of the atmosphere via solar occultation in which sunlight is used as a light source as it passes through the atmosphere at sunrise and sunset. The satellite has an orbital period of $97.6 \mathrm{~min}$, allowing it to make measurements about every $49 \mathrm{~min}$. The latitude of the measurement tangent point varies slowly with time (Fig. 1) but accumulates a set of global measurements in about 2 months. The geographic measurement cycle repeats in latitude annually (with a small degree of slippage), which provides a framework for determining trends as a function of time.

The analysis of ACE-FTS spectra begins by deriving altitude profiles for pressure and temperature through the analysis of $\mathrm{CO}_{2}$ lines in the spectra, using an assumed profile for the $\mathrm{CO}_{2}$ volume mixing ratio (VMR) below $60 \mathrm{~km}$ (Boone et al., 2013). The VMR profile for a particular molecule or isotopologue of interest is then retrieved via the analysis of a set of microwindows: a collection of relatively small (typically less than $0.5 \mathrm{~cm}^{-1}$ ) portions of the spectrum containing spectral features primarily from the target atmospheric constituent. Spectroscopic data employed in the forward model calculations in version 3.5 processing come mostly from the HITRAN 2008 database (Rothman et al., 2009).

Retrievals of ACE-FTS methane data were obtained using the latest version 3.5 of the ACE-FTS software (Boone et al., 2013). These retrievals are performed in the same way as those from version 3.0 (Boone et al., 2005) but include a fix of a problem with pressure and temperature information obtained from the Canadian Meteorological Center for measurements after September 2010. Briefly, the retrieval employs a nonlinear least-squares global fitting approach, 

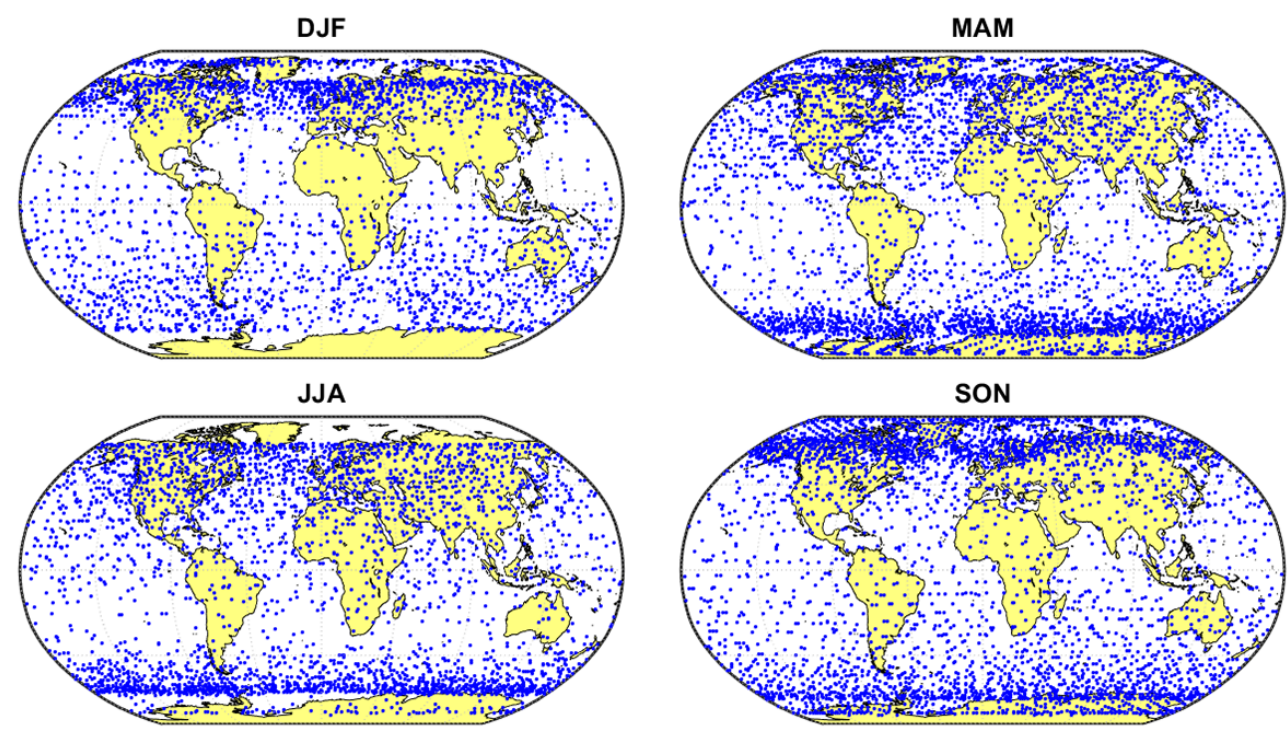

Figure 2. Location of all $\mathrm{ACE} \mathrm{CH}_{4}$ measurements by season.

where the volume mixing ratio altitude profiles for the target molecule and all significant interferers (molecules or isotopologues other than the target that feature significant absorption within the set of microwindows) are determined simultaneously. No constraints from a priori information are employed in this process, and therefore no averaging kernels are produced.

The microwindows corresponding to the $v_{4}, 2 v_{4}$, and $v_{3}$ vibrational bands of $\mathrm{CH}_{4}$ were used for these retrievals. The fundamental $\nu_{4}$ and $\nu_{3}$ bands are used at higher altitudes while the $2 v_{4}$ overtone band is used at lower altitudes where the fundamentals are saturated. A summary of the microwindows used in the current study is given in Table 1 while the full microwindow list is given in the Supplement.

Note that the microwindow set for the main isotopologue is different from that employed in normal version 3.5 processing. Preliminary results in the current study indicated problems in the main isotopologue results that yielded sharp, latitude-independent, systematic features in the derived $\delta \mathrm{D}$ and $\delta^{13} \mathrm{C}$ plots. Such features were also present in recently published ACE data of $\delta^{13} \mathrm{C}-\mathrm{CO}$ (Beale et al., 2015). Therefore, a research product was generated for the molecule using a new microwindow set. This new set featured more microwindows between 40 and $50 \mathrm{~km}$ than the version $3.5 \mathrm{mi}-$ crowindow set, as well as more microwindows at low altitudes (below $25 \mathrm{~km}$ ). Spectroscopic parameters (positions, line widths, pressure shifts, and intensities) for $\mathrm{CH}_{4}$ lines in the $2 v_{4}$ band were adjusted to improve fitting residuals (which are poor when using existing spectroscopic data for these lines) and to improve the internal consistency between the intensities of lines in this band and lines in the other two bands employed in the retrieval. These sharp features are still present in the data presented here, but their magni- tudes are greatly reduced. Some further discussion of these adjustments are given in Appendix A.

For the main isotopologue of methane, random errors from the least-squares fitting process are in the range of 2 to $6 \%$ over the range of altitudes employed in the current study. For ${ }^{13} \mathrm{CH}_{4}$, fitting errors range from 2 to $6 \%$ below $30 \mathrm{~km}$, and the errors increase for altitudes above $30 \mathrm{~km}$, reaching $10 \%$ near the upper-altitude limit of the retrieval. For $\mathrm{CH}_{3} \mathrm{D}$, fitting errors range from 4 to $12 \%$ below $15 \mathrm{~km}$ and increase for higher altitudes, approaching $30 \%$ near the upper-altitude limit of the retrieval.

Spacing of retrieval altitudes for VMR profiles of the isotopologues of methane varies from $\sim 2 \mathrm{~km}$ (low altitudes) to $6 \mathrm{~km}$ (high altitudes) and averages around $4 \mathrm{~km}$. The profiles were interpolated onto a $1 \mathrm{~km}$ grid using a piecewise quadratic interpolation. Then, the profiles were placed into seasonal bins and $10^{\circ}$ latitude bins. Figure 2 shows the spatial distribution of the profiles by season. Most of the profiles are at higher latitudes, but there are at least 40 profiles in each equatorial bin every season. The binning process averages the results from many occultations in order to reduce the impact of the random error on the results (the random error decreases according to the square root of the number of elements included in the average).

Model calculations were performed using version 4 of the Whole Atmospheric Community Climate Model (WACCM), a component of the Community Earth System Model (Marsh et al., 2013). WACCM extends from the surface to $5 \times 10^{-6} \mathrm{hPa}(\sim 140 \mathrm{~km})$ and includes fully interactive chemistry and circulations patterns for the whole atmosphere. WACCM can be run as a standalone model or as the atmospheric component of CESM. 
Table 1. Summary of microwindows used by ACE for retrieval of $\mathrm{CH}_{4}$.

\begin{tabular}{llll}
\hline Isotopologue & $\begin{array}{l}\text { Number of } \\
\text { microwindows }\end{array}$ & $\begin{array}{l}\text { Altitude } \\
\text { range }(\mathrm{km})\end{array}$ & Wave number ranges $\left(\mathrm{cm}^{-1}\right)$ \\
\hline $\mathrm{CH}_{4}$ & 74 & $5-75$ & $1139,1219-1374,1672,1876,1950,2610-3086$ \\
$\mathrm{CH}_{3} \mathrm{D}$ & 45 & $5-35$ & $923-1480,2623-3096$ \\
${ }^{13} \mathrm{CH}_{4}$ & 36 & $5-50$ & $1202-1339,1950,2566-2839$ \\
\hline
\end{tabular}

Table 2. Kinetic isotope effect ratios of methane with $\mathrm{OH}, \mathrm{O}^{1} \mathrm{D}$, and $\mathrm{Cl}$.

\begin{tabular}{lllll}
\hline Reactant & $K_{\mathrm{H}} / k_{\mathrm{D}}$ & $k_{12} / k_{13}$ & Temperature & Ref. \\
\hline $\mathrm{OH}$ & $1.294 \pm 0.018$ & $1.0039 \pm 0.0004$ & $296 \mathrm{~K}$ & Saueressig et al. (2001) \\
$\mathrm{O}^{1} \mathrm{D}$ & 1.06 & 1.013 & $296 \mathrm{~K}$ & Saueressig et al. (2001) \\
$\mathrm{Cl}$ & $1.47 \pm 0.03$ & $1.06 \pm 0.01$ & $298 \mathrm{~K}$ & Feilberg et al. (2005) \\
\hline
\end{tabular}

Out of the box, WACCM does not support molecular isotopologues, but the two isotopologues of $\mathrm{CH}_{4}$ can be inserted as separate species with a few modifications. First, the reactions of the first step of methane oxidation are duplicated and their rate constants adjusted by the kinetic isotope effects $k_{\mathrm{D}} / k_{\mathrm{H}}$ and $k_{12} / k_{13}$. The KIE of methane with each oxidant is given in Table 2 and the full set of modified reactions is listed in Table 3. No further reactions or molecules are modified as only the isotopic composition of methane is studied here. Next, new photolytic cross sections were added for all three isotopologues (Lee et al., 2001; Nair et al., 2005). The blue shifts of the cross sections are approximately $1 \mathrm{~nm}$ for $\mathrm{CH}_{3} \mathrm{D}$ and $0.04 \mathrm{~nm}$ for ${ }^{13} \mathrm{CH}_{4}$. Finally, boundary conditions representing surface emissions were calculated for the two heavy isotopologues. Keeling plots presented by Röckmann et al. (2011) were used to derive relations between $\left[\mathrm{CH}_{4}\right]$ vs. $\delta \mathrm{D}$ and $\delta^{13} \mathrm{C}$ :

$\delta \mathrm{D}=\frac{1.50 \times 10^{4}}{\left[\mathrm{CH}_{4}\right] /(\mathrm{ppm})}-55.6 \%$,

$\delta^{13} \mathrm{C}=\frac{1.29 \times 10^{4}}{\left[\mathrm{CH}_{4}\right] /(\mathrm{ppm})}-151.4 \%$.

These relations were applied to the existing $\mathrm{CH}_{4}$ boundary conditions used by WACCM (Lamarque et al., 2010) to derive boundary conditions for $\mathrm{CH}_{3} \mathrm{D}$ and ${ }^{13} \mathrm{CH}_{4}$.

WACCM was run as a standalone model with a resolution of $4 \times 5^{\circ}$ (latitude/longitude) and 66 vertical levels. The model was run as a perpetual year 2000 for a total of 20 years: 17 years of spin-up time followed by 3 years that were analyzed. Data from WACCM was analyzed in two ways. First, to observe general trends, the entire data set from the final 3 years was averaged monthly and placed into $10^{\circ}$ latitude bins. Second, to remove sampling bias from ACE when comparing to WACCM, a smaller data set was constructed by measuring "profiles" from the whole WACCM data set at the same times and locations as each ACE profile. This data set was averaged seasonally and placed into $10^{\circ}$ latitude bins to match the analysis of ACE data.

\section{Results}

Figure 3 shows the total concentration of methane as a function of latitude and altitude as measured by ACE. In the wellmixed troposphere, the concentration of methane is nearly constant at around $1750 \mathrm{ppb}$. Above the tropopause, methane concentrations decrease steadily at higher altitudes to about $300 \mathrm{ppb}$ at $20-25 \mathrm{~km}$ above the tropopause. Methane near the equator extends higher into the atmosphere primarily due to the higher tropopause, as well as the transport of air containing elevated levels of methane from the troposphere to the lower stratosphere in the tropics (as part of the Brewer-Dobson circulation). Some seasonal variation is visible. Pockets of methane-depleted air are present over the poles especially during the summer and fall months: December to May over the South Pole and June to November over the North Pole.

ACE data for $\delta \mathrm{D}$ as a function of latitude and altitude are plotted in Fig. 4. $\mathrm{CH}_{3} \mathrm{D}$ data are available from 5 to $30-35 \mathrm{~km}$, depending on latitude. Above $12 \mathrm{~km}$, values of $\delta \mathrm{D}$ steadily increase with altitude from tropospheric values around $0 \%$, then sharply increase at the highest few kilometers of the available data to between +250 and $+400 \%$. This sharp increase occurs at the same altitudes where the fitting errors during retrieval are the highest. In addition, high levels of $\mathrm{CH}_{3} \mathrm{D}$ are noticeably present over the South Pole from June to November. Below $12 \mathrm{~km}$, the $\delta \mathrm{D}$ data are much noisier and average around $+35 \%$. This "step function" in the plot, with a sharp change in $\delta \mathrm{D}$ at a particular altitude that does not vary with latitude, likely indicates a problem in the retrieval below $12 \mathrm{~km}$ for either $\mathrm{CH}_{3} \mathrm{D}$ or the main isotopologue. An additional horizontal line is present around $20 \mathrm{~km}$ and is discussed with $\delta^{13} \mathrm{C}$ below. Finally, there is another artifact present below $80^{\circ} \mathrm{S}$ in June-August: a single alti- 
Table 3. Kinetic constants of reactions modified to include the heavy isotopologues of methane used with WACCM. Temperature-independent reactions use a single rate constant $A$ in units of $\mathrm{cm}^{3}$ molecule ${ }^{-1} \mathrm{~s}^{-1}$. Temperature-dependent reactions have a rate constant given by the equation $k(T)=A \times \exp (-E / R T)$. The factor $E / R$ has units of $\mathrm{K}^{-1}$.

\begin{tabular}{llll}
\hline Reaction & $A$ & $E / R$ & Ref. \\
\hline $\mathrm{CH}_{4}+\mathrm{OH} \rightarrow \mathrm{CH}_{3}+\mathrm{H}_{2} \mathrm{O}$ & $2.45 \times 10^{-12}$ & 1775 & Sander et al. (2006) \\
${ }^{13} \mathrm{CH}_{4}+\mathrm{OH} \rightarrow \mathrm{CH}_{3}+\mathrm{H}_{2} \mathrm{O}$ & $2.44 \times 10^{-12}$ & 1775 & Sander et al. (2006) \\
$\mathrm{CH}_{3} \mathrm{D}+\mathrm{OH} \rightarrow \mathrm{CH}_{3}+\mathrm{H}_{2} \mathrm{O}$ & $3.50 \times 10^{-12}$ & 1950 & Sander et al. (2006) \\
$\mathrm{CH}_{4}+\mathrm{Cl} \rightarrow \mathrm{CH}_{3}+\mathrm{HCl}$ & $7.30 \times 10^{-12}$ & 1280 & Sander et al. (2006) \\
${ }^{13} \mathrm{CH}_{4}+\mathrm{Cl} \rightarrow \mathrm{CH}_{3}+\mathrm{HCl}$ & $6.89 \times 10^{-12}$ & 1280 & Sander et al. (2006) \\
$\mathrm{CH}_{3} \mathrm{D}+\mathrm{Cl} \rightarrow \mathrm{CH}_{3}+\mathrm{HCl}$ & $7.00 \times 10^{-12}$ & 1380 & Feilberg et al. (2005) \\
$\mathrm{CH}_{4}+\mathrm{O}\left({ }^{1} \mathrm{D}\right) \rightarrow \mathrm{CH}_{3}+\mathrm{OH}$ & $1.31 \times 10^{-10}$ & & Sander et al. (2006) \\
$\mathrm{CH}_{4}+\mathrm{O}\left({ }^{1} \mathrm{D}\right) \rightarrow \mathrm{CH}_{2} \mathrm{O}+\mathrm{H}+\mathrm{HO}_{2}$ & $3.00 \times 10^{-11}$ & & Sander et al. (2006) \\
$\mathrm{CH}_{4}+\mathrm{O}\left({ }^{1} \mathrm{D}\right) \rightarrow \mathrm{CH}_{2} \mathrm{O}+\mathrm{H}_{2}$ & $7.50 \times 10^{-12}$ & & Sander et al. (2006) \\
${ }^{13} \mathrm{CH}_{4}+\mathrm{O}\left({ }^{1} \mathrm{D}\right) \rightarrow \mathrm{CH}_{3}+\mathrm{OH}$ & $1.11 \times 10^{-10}$ & & Saueressig et al. (2001) \\
${ }^{13} \mathrm{CH}_{4}+\mathrm{O}\left({ }^{1} \mathrm{D}\right) \rightarrow \mathrm{CH}_{2} \mathrm{O}+\mathrm{H}+\mathrm{HO}_{2}$ & $2.96 \times 10^{-11}$ & & Saueressig et al. (2001) \\
${ }^{13} \mathrm{CH}_{4}+\mathrm{O}\left({ }^{1} \mathrm{D}\right) \rightarrow \mathrm{CH}_{2} \mathrm{O}+\mathrm{H}_{2}$ & $7.40 \times 10^{-12}$ & & Saueressig et al. (2001) \\
$\mathrm{CH}_{3} \mathrm{D}+\mathrm{O}\left({ }^{1} \mathrm{D}\right) \rightarrow \mathrm{CH}_{3}+\mathrm{OH}$ & $1.06 \times 10^{-10}$ & & Saueressig et al. (2001) \\
$\mathrm{CH}_{3} \mathrm{D}+\mathrm{O}\left({ }^{1} \mathrm{D}\right) \rightarrow \mathrm{CH}_{2} \mathrm{O}+\mathrm{H}+\mathrm{HO}_{2}$ & $2.83 \times 10^{-11}$ & & Saueressig et al. (2001) \\
$\mathrm{CH}_{3} \mathrm{D}+\mathrm{O}\left({ }^{1} \mathrm{D}\right) \rightarrow \mathrm{CH}_{2} \mathrm{O}+\mathrm{H}_{2}$ & $7.08 \times 10^{-12}$ & & Saueressig et al. (2001) \\
$\mathrm{CH}_{4}+\mathrm{h} v \rightarrow$ products & & & Lee et al. (2001) \\
${ }^{13} \mathrm{CH}_{4}+\mathrm{h} v \rightarrow$ products & & & Lee et al. (2001) \\
$\mathrm{CH}_{3} \mathrm{D}+\mathrm{h} v \rightarrow$ products & & & Nair et al. (2005) \\
\hline & & &
\end{tabular}
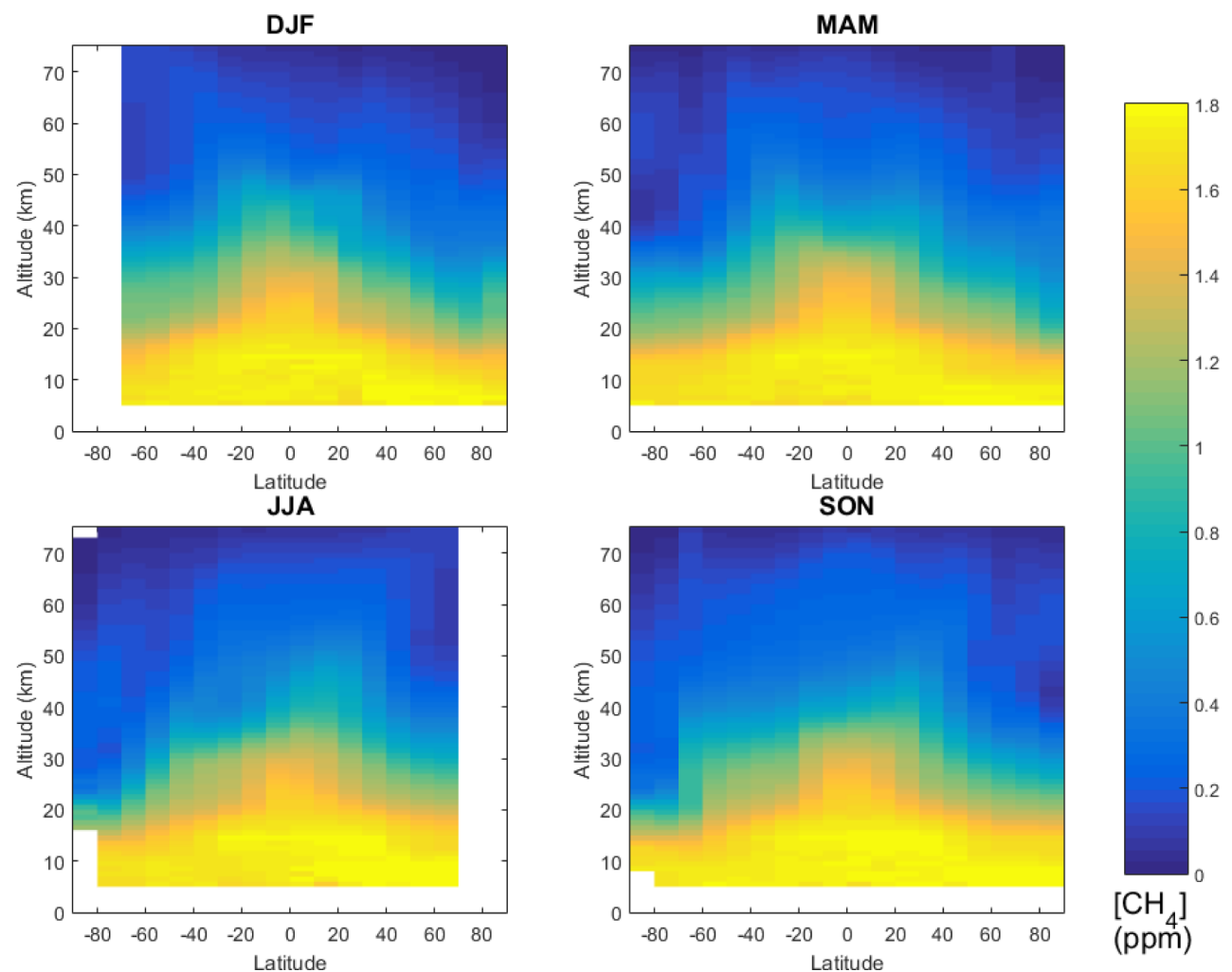

Figure 3. ACE total methane concentration by season. 

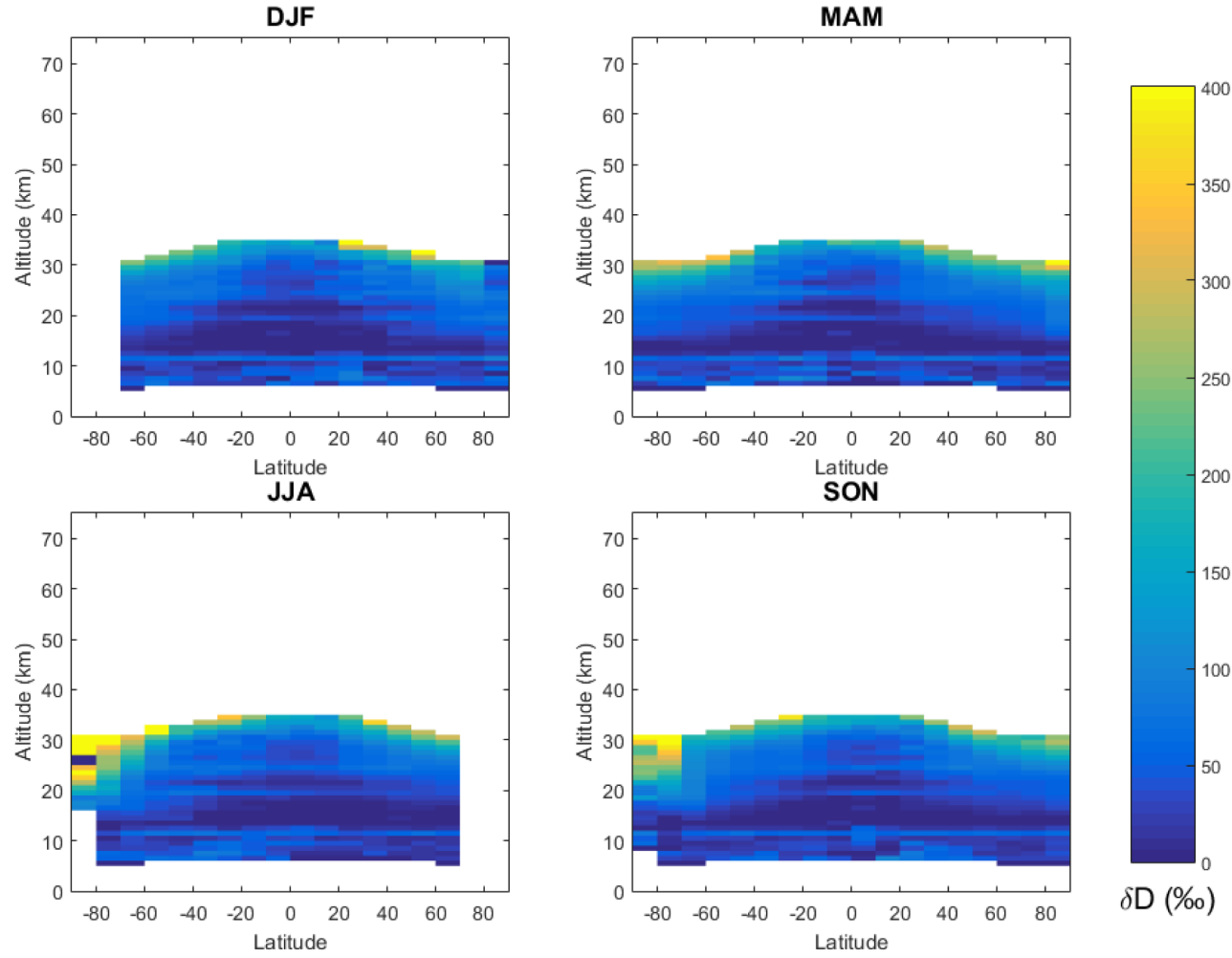

Figure 4. ACE $\delta \mathrm{D}$ by season.
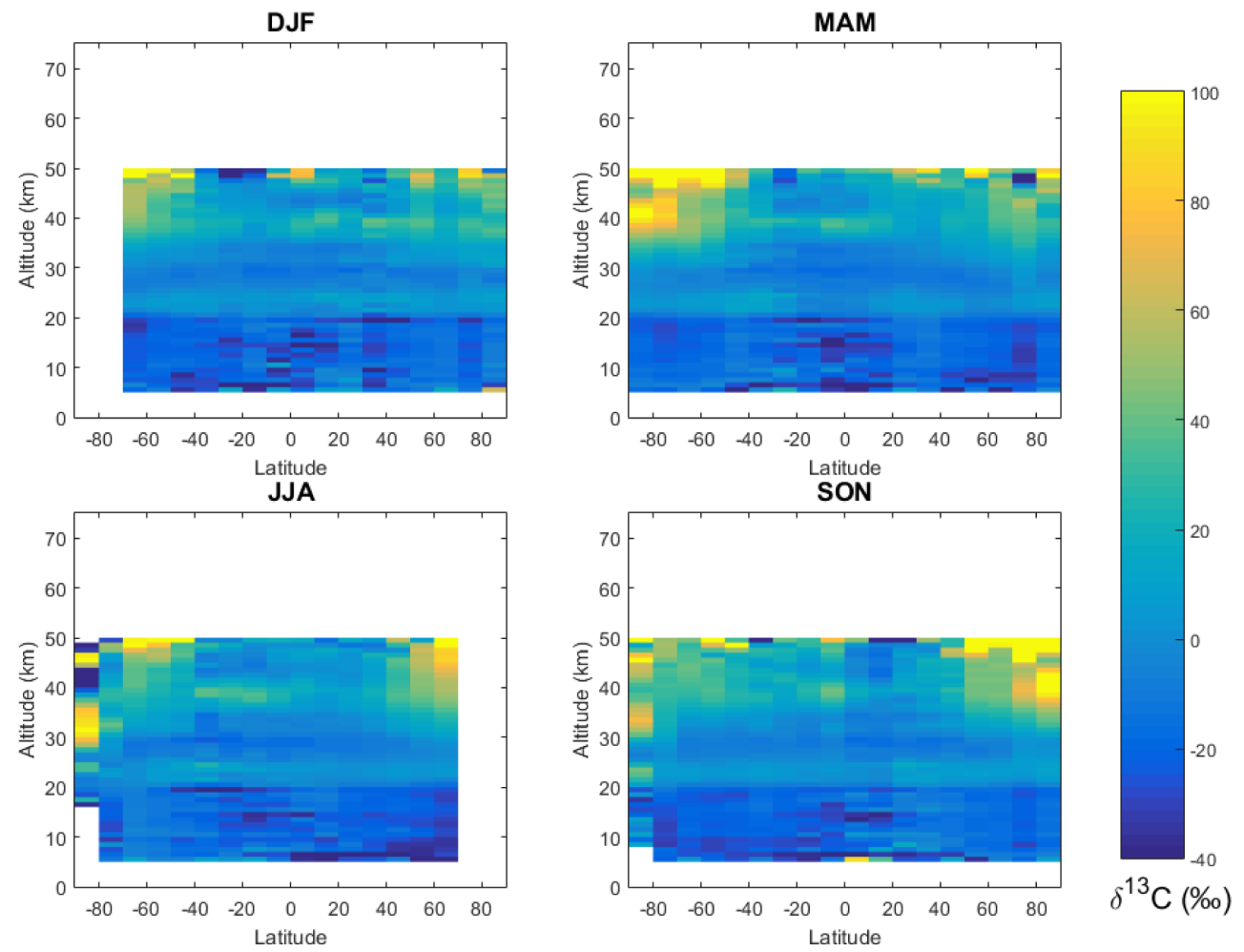

Figure 5. ACE $\delta^{13} \mathrm{C}$ by season. 

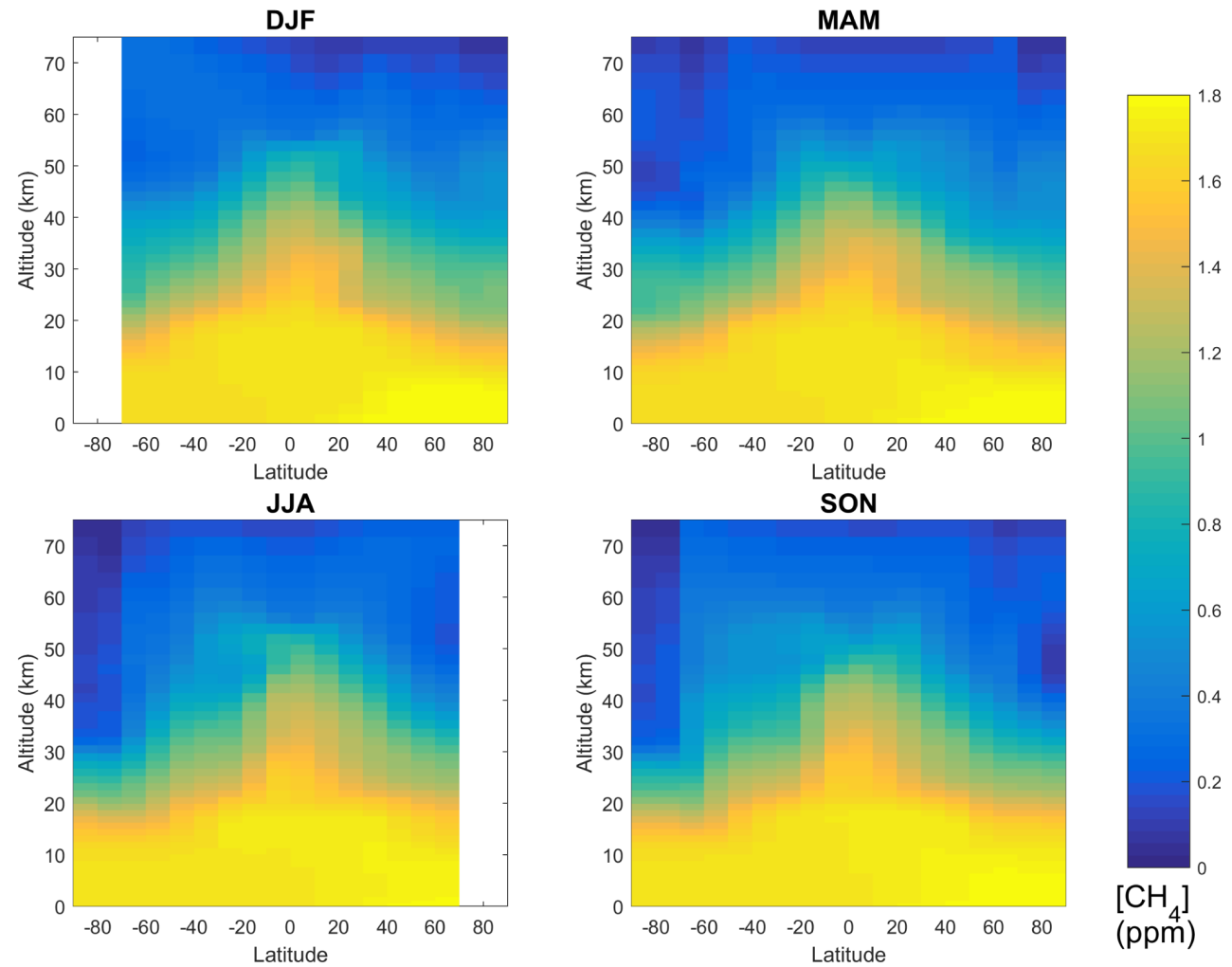

Figure 6. Total methane concentration by season from the ACE-sampled WACCM data set. Especially low levels of $\mathrm{CH}_{4}$ appear over the South Pole between June and December. In reality, these levels are only present in August and September as shown in the Supplement, but the WACCM sampling method is biased toward those 2 months at those latitudes.
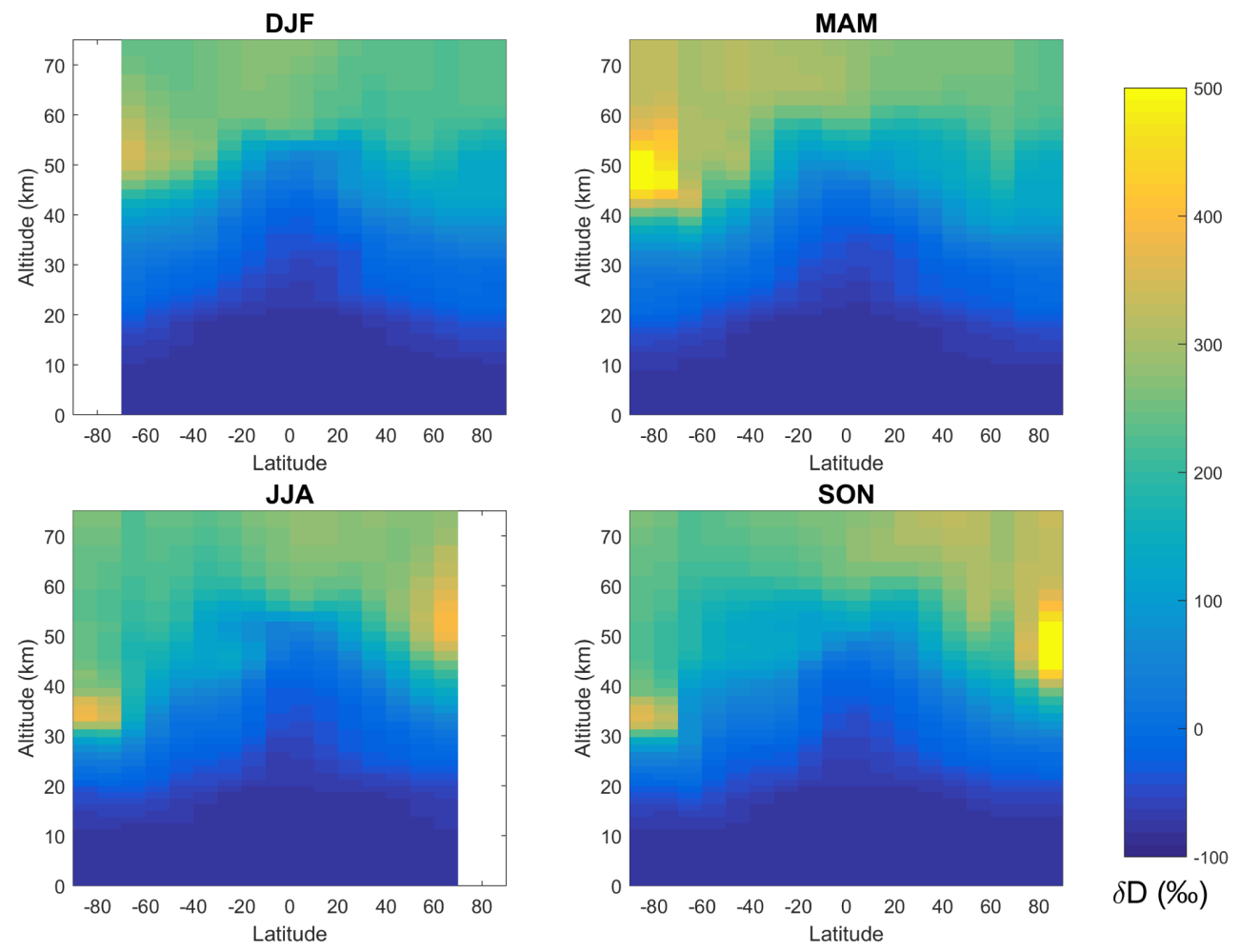

Figure 7. $\delta \mathrm{D}$ by season from the ACE-sampled WACCM data set. 

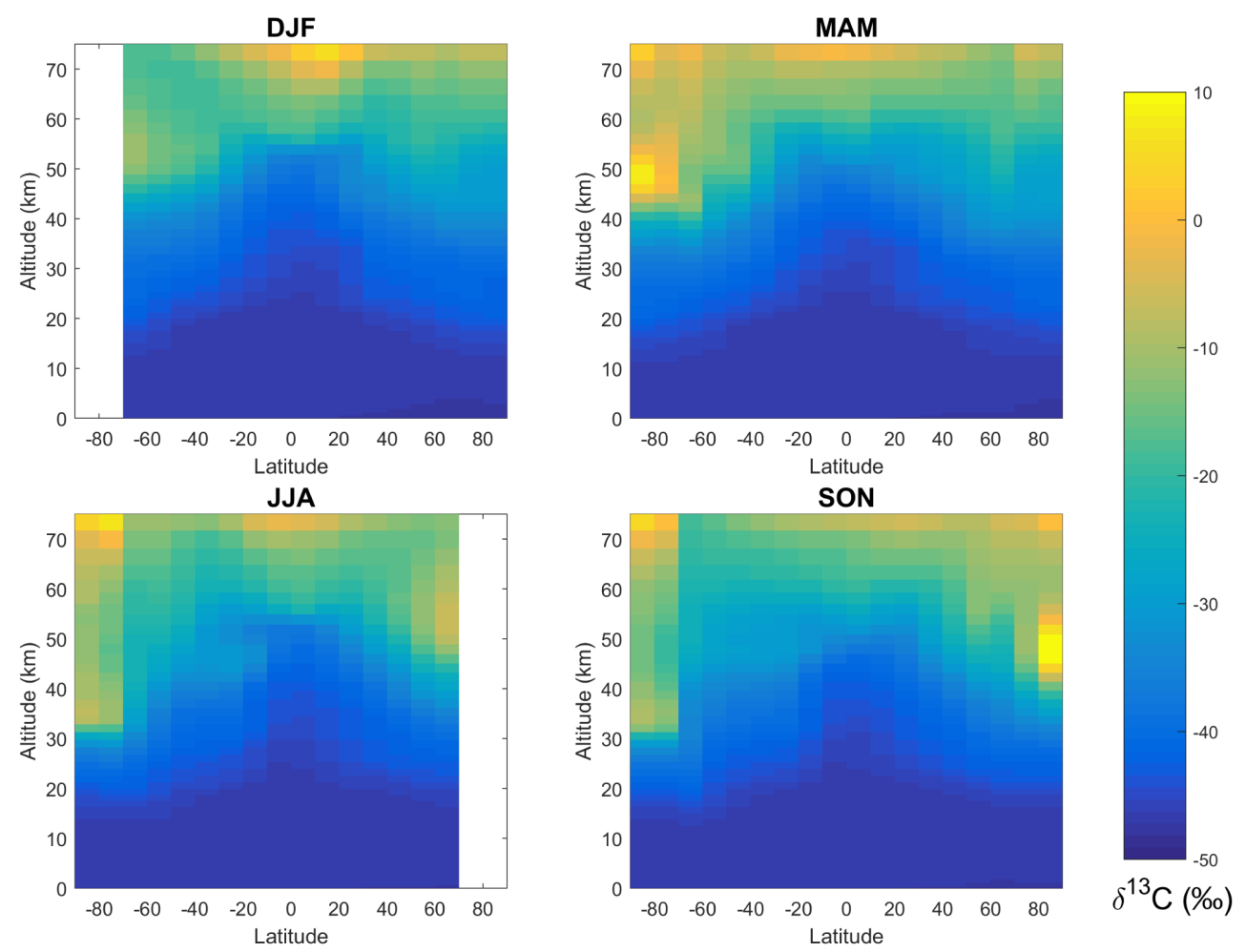

Figure 8. $\delta^{13} \mathrm{C}$ by season from the ACE-sampled WACCM data set.

tude with a very low $\delta \mathrm{D}$. This is due to the low number and quality of measurements taken over the poles caused by the satellite's non-polar orbit.

ACE data for $\delta^{13} \mathrm{C}$ are plotted in Fig. 5. These data are available from 6 to $50 \mathrm{~km}$ except over the poles during some seasons. Overall the data are noisier than for $\delta \mathrm{D}$, but values of $\delta^{13} \mathrm{C}$ still increase with altitude. Tropospheric values average near $-20 \%$, while lower stratospheric values average near $0 \%$. Seasonal changes are also more apparent than in $\delta \mathrm{D}$. Enrichment of ${ }^{13} \mathrm{C}$ is strongest during the summer and fall months. Values of $\delta^{13} \mathrm{C}$ as high as $+100 \%$ are present over both poles between 35 and $50 \mathrm{~km}$. Higher $\delta^{13} \mathrm{C}$ values are present in two bands at 22 and $40 \mathrm{~km}$. Since these bands show no variation in altitude as a function of latitude, they are also believed to be artifacts of the retrieval process.

Note that there was a very large step function in the original version $3.5 \delta^{13} \mathrm{C}$ results around 22 and $40 \mathrm{~km}$, a consequence of poor internal consistency between the spectroscopic data for the $\mathrm{CH}_{4}$ lines used to derived $\mathrm{CH}_{4} \mathrm{VMR}$ at low altitudes and the $\mathrm{CH}_{4}$ lines used for the high-altitude portion of the retrieval. This also affected $\delta \mathrm{D}$, resulting in a band at around $20 \mathrm{~km}$. For the $\mathrm{CH}_{4}$ research product employed in the current study, the intensities of $\mathrm{CH}_{4}$ lines in the $2 v_{4}$ band (the lines that contribute to retrieved $\mathrm{CH}_{4} \mathrm{VMR}$ at low altitude) were adjusted in an effort to improve the agreement with other $\mathrm{CH}_{4}$ bands employed in the retrieval (i.e., the bands that contribute to the retrieved VMR at higher alti- tudes). The step function in the $\mathrm{ACE} \delta^{13} \mathrm{C}$ results was greatly reduced, but the "bump" in $\delta^{13} \mathrm{C}$ near $22 \mathrm{~km}$ suggests that there may remain a spectroscopic compatibility problem for $\mathrm{CH}_{4}$ lines in different bands. These features also appear in ACE observations of $\delta^{13} \mathrm{C}-\mathrm{CO}$ (Beale et al., 2015) for the same reason, suggesting that they are artifacts of the retrieval.

The ACE-sampled WACCM data set is presented in Fig. 6 (total $\left.\mathrm{CH}_{4}\right)$, Fig. $7(\delta \mathrm{D})$, and Fig. $8\left(\delta^{13} \mathrm{C}\right)$. Figures of the full WACCM data set are present in the Supplement. The model output of total methane agrees well with ACE's observations. Tropospheric methane fluctuates slightly by season but is steady around $1700 \mathrm{ppb}$. The plume of methane-rich air over the equator in the stratosphere is also present, and mixing ratios of methane decrease with higher altitudes in the stratosphere and mesosphere. Seasonal variation is noticeable here; air masses low in methane form over each pole around $50 \mathrm{~km}$ during the summer, then sink and become further depleted during the fall.

These seasonal trends are especially visible in $\delta \mathrm{D}$ and $\delta^{13} \mathrm{C}$. The polar air masses of depleted $\mathrm{CH}_{4}$ are enriched in both $\mathrm{CH}_{3} \mathrm{D}$ and ${ }^{13} \mathrm{CH}_{4}$ and become further enriched as they sink. Enrichment in the southern air mass reaches a lower altitude and lingers for a longer period, February to June, than the northern air mass which is enriched only from July to October. This difference in altitude is also shown in ACE; enrichment in the Southern Hemisphere reaches low enough 

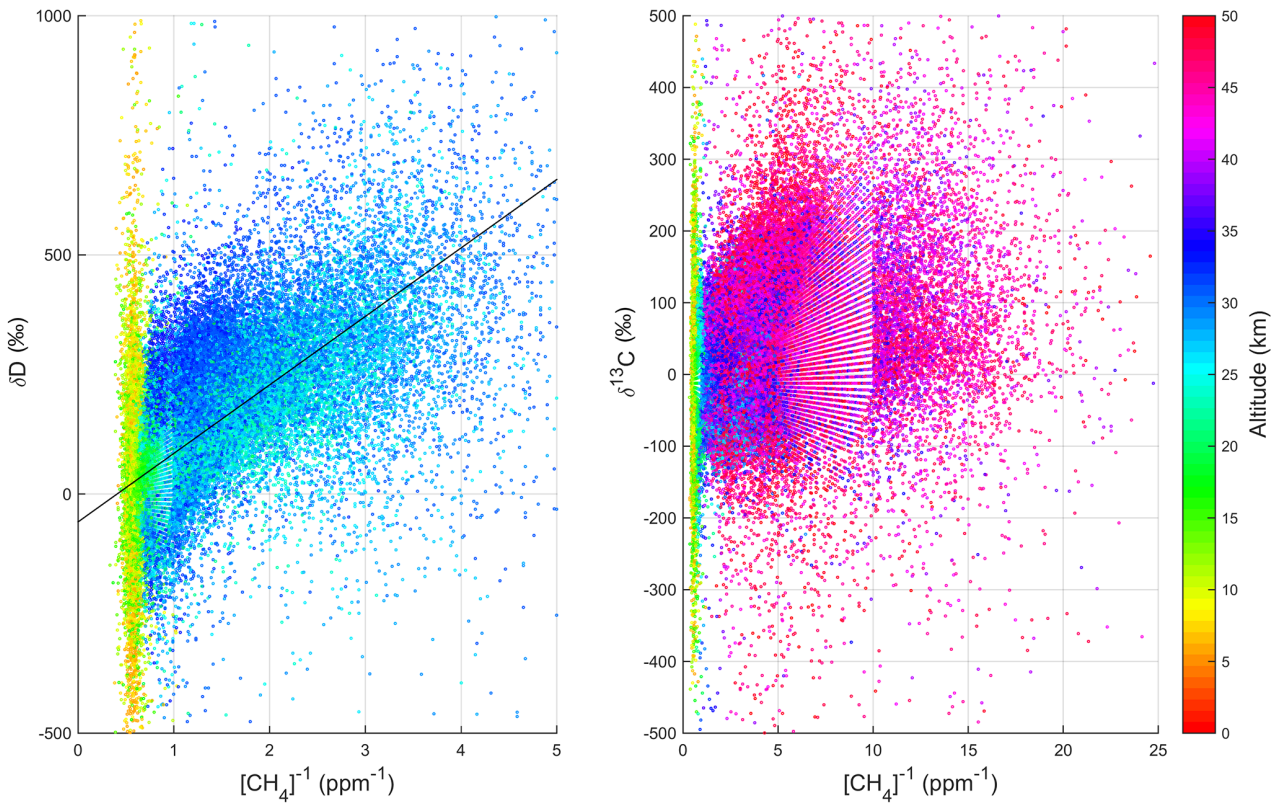

Figure 9. Keeling plots of ACE data for $\delta \mathrm{D}$ (left) and $\delta{ }^{13} \mathrm{C}$ (right). Each data point is color-coded by its measurement altitude. The streaks of data present in the right figure are artifacts; ACE measurements are retrieved to three significant figures, causing a sharp change in precision around $10 \mathrm{ppm}^{-1}$ (e.g., $9.99 \mathrm{ppm}$ vs. $10.1 \mathrm{ppm}$ ).

to be detected by ACE, while enrichment in the Northern Hemisphere remains too high to be measurable by ACE.

\section{Discussion}

\subsection{Keeling plots of ACE data}

As mentioned previously, the total concentration of atmospheric methane has an inverse relationship with $\delta \mathrm{D}$ and $\delta{ }^{13} \mathrm{C}$ as shown in a Keeling plot. Keeling plots for both isotopologues are given in Fig. 9 by plotting the reciprocal of the methane mixing ratio against $\delta \mathrm{D}$ and $\delta^{13} \mathrm{C}$ for each altitude in every ACE profile. In these figures, the expected relationship should appear as a sloped line. Such a slope is visible for $\delta \mathrm{D}$ at stratospheric altitudes. However, there is still a significant range of $\delta \mathrm{D}$ values for a given mixing ratio of methane, especially in the troposphere where methane has little spatial variability due to being well mixed. For ${ }^{13} \mathrm{CH}_{4}$, a relationship between total methane and $\delta^{13} \mathrm{C}$ is much more difficult to distinguish. This is not surprising considering that the $\delta^{13} \mathrm{C}$ data have a larger range of values than the $\delta \mathrm{D}$ data. Several streaks are also visible in the $\delta^{13} \mathrm{C}$ data but are considered artifacts; since molecular concentrations from ACE are reported to three significant figures, a sharp change in precision occurs at multiples of 10 , causing the data points to clump together into lines at just above $10 \mathrm{ppm}$. A similar artifact is slightly visible in $\delta \mathrm{D}$ at $1 \mathrm{ppm}$.

\subsection{Comparison to WACCM output}

In general, ACE and WACCM have good qualitative agreement with each other. The most noticeable shared feature between the two is the presence of masses of enriched isotopes over the poles. In the ACE data for $\mathrm{CH}_{3} \mathrm{D}$, the only visible seasonal change is an increase in $\delta \mathrm{D}$ over the South Pole during the winter (JJA). WACCM also shows this enrichment at the same time. Enrichment over the North Pole is not visible in the ACE data, but WACCM shows that $\mathrm{CH}_{3} \mathrm{D}$ enriched air does not descend to altitudes low enough to be measurable with ACE. In addition, the rapid increase in enrichment at the highest altitudes, $30-35 \mathrm{~km}$, measured by ACE at all latitudes is not present at the same location in WACCM. Increased enrichment is observable above $40 \mathrm{~km}$ in WACCM, but the magnitude of this increase is much smaller. This suggests that the feature in ACE is not a real phenomenon, but rather it is possibly some systematic effect associated with the data near the upper-altitude limit of the $\mathrm{CH}_{3} \mathrm{D}$ retrievals, a consequence of pushing the retrievals to altitudes where the spectra contain minimal signal from the isotopologue.

Though $\delta^{13} \mathrm{C}$ data from ACE are much noisier than for $\delta \mathrm{D}$, seasonal enrichment over both poles is visible as the $\delta^{13} \mathrm{C}$ data extend to high altitudes. In both ACE and WACCM, enrichment over the South Pole is most visible in the fall (MAM) months with slightly lower enrichment during the winter (JJA) and spring (SON). The same trend is present over the North Pole in the fall (SON), but again the amount of enrichment fades more rapidly with time as it did with $\mathrm{CH}_{3} \mathrm{D}$. 

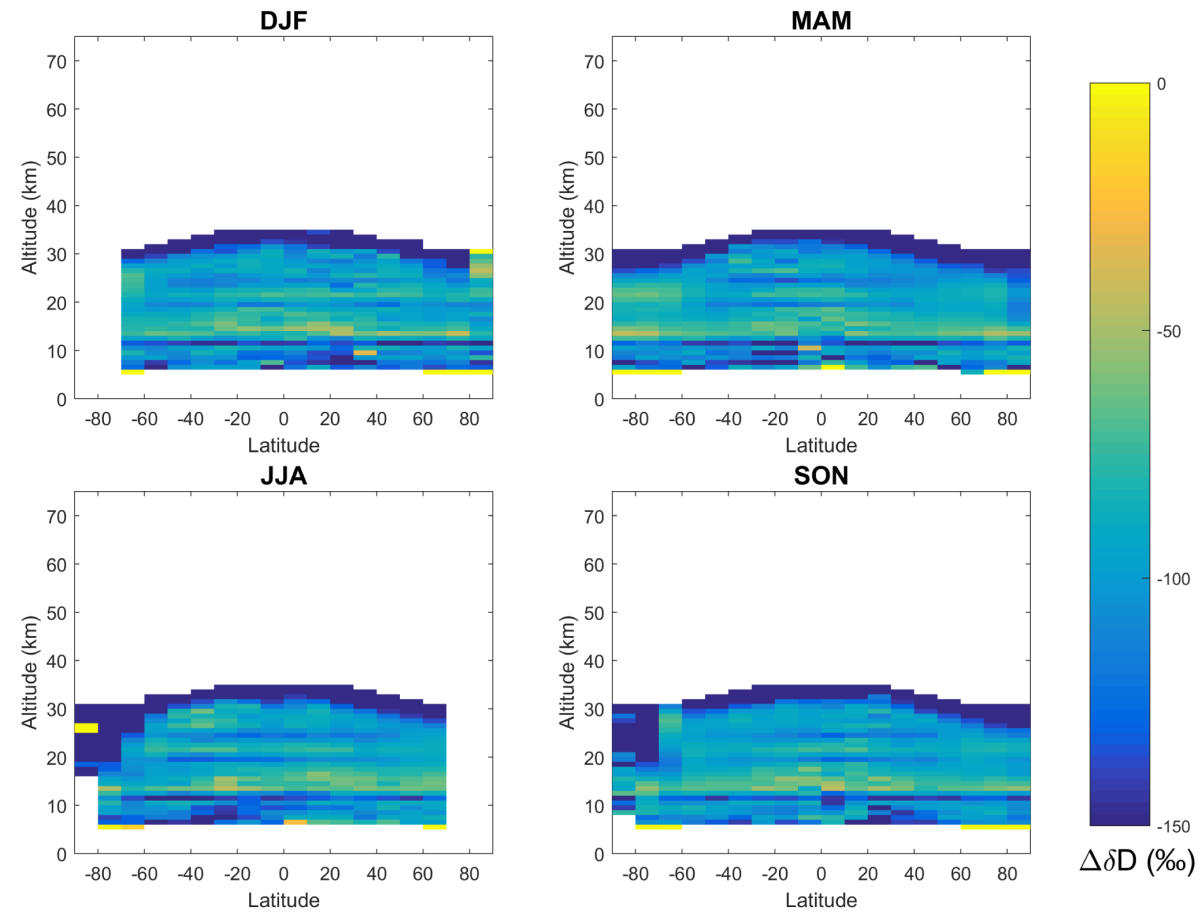

Figure 10. The difference in $\delta \mathrm{D}$ between ACE and WACCM. Negative values are given when ACE reports a larger value than WACCM.

However, ACE and WACCM disagree greatly over the values of $\delta \mathrm{D}$ and $\delta^{13} \mathrm{C}$. ACE reports values of $\delta^{13} \mathrm{C}$ of over $+100 \%$ in highly enriched areas, while WACCM reports $\delta^{13} \mathrm{C}$ values only up to $+5 \%$ at the altitudes measured by ACE. Tropospheric values are closer, but there is still a disparity: ACE measures $\delta^{13} \mathrm{C}$ around $-20 \%$ while WACCM reports it at around $-45 \%$. The difference is more pronounced with $\delta \mathrm{D}$. Tropospheric values of $\delta \mathrm{D}$ differ by $100 \%$ o between ACE and WACCM. A quantitative comparison of $\delta \mathrm{D}$ in the stratosphere is more difficult due to the sharp increase seen in ACE.

Systematic errors in the ACE $\mathrm{CH}_{4}$ results are clearly dominated by errors in the spectroscopic constants. Although dramatically improved compared to the preliminary results that used the version 3.5 processing, there remain sharp latitudeindependent features at particular altitudes in the fractionation plots in the current study using the research product for main isotopologue $\mathrm{CH}_{4}$. While the new spectroscopic parameters derived for the main isotopologue of $\mathrm{CH}_{4}$ significantly improve the fitting residuals and reduce the magnitudes of the sharp features in the fractionation plots, further work is clearly required to refine the quality of these spectroscopic constants. It is not clear at this time what contributions to the systematic features are from the main isotopologue vs. the subsidiary isotopologues. With the magnitudes of the uncertainties involved, there seems little value in generating a formal, quantitative estimate of the systematic error; the errors are large enough (the $\delta \mathrm{D}$ curve was more than $9 \%$ different from expectations, and the $\delta^{13} \mathrm{C}$ curve was more than $2 \%$ dif- ferent) to necessitate generating new spectroscopic constants for at least some portion of the $\mathrm{CH}_{4}$ lines in the microwindows employed for the ACE-FTS retrievals.

\subsection{Calibration of ACE data}

In the troposphere, WACCM's predictions of $\delta \mathrm{D}$ and $\delta^{13} \mathrm{C}$ agree with previous measurements. For $\delta^{13} \mathrm{C}$, WACCM predicts a tropospheric value of $-47 \%$, while measurements range from -48 to $-46 \%$ (Conny and Currie, 1996; Sugawara et al., 1997; Umezawa et al., 2012). Tropospheric $\delta \mathrm{D}$ measurements have a larger range, between -100 and $-75 \%$ (Rice et al., 2003; Umezawa et al., 2012). WACCM lies on the high end of this, between -81 and $-78 \%$, with more a negative $\delta \mathrm{D}$ in the Northern Hemisphere. Based on this agreement, WACCM can be used to calibrate ACE by accounting for the unknown systemic error in the ACE retrievals of $\mathrm{CH}_{3} \mathrm{D}$ and ${ }^{13} \mathrm{CH}_{4}$. These calibration factors, one for each isotopologue, are a shift applied to $\delta \mathrm{D}$ and $\delta^{13} \mathrm{C}$ from ACE and are equivalent to a multiplication factor applied to the $\mathrm{CH}_{3} \mathrm{D}$ and ${ }^{13} \mathrm{CH}_{4}$ VMR profiles retrieved by ACE. The calibration factors were derived by taking the difference of the median tropospheric $\delta$ value for both isotopologues of ACE and WACCM. The height of the tropopause for each ACE profile was taken from derived meteorological products provided by Manney et al. (2007) and was between 8 and $16 \mathrm{~km}$ for most profiles. The calculated calibration shifts are $-92.4 \%$ for $\delta \mathrm{D}$ and $-21.8 \%$ for $\delta^{13} \mathrm{C}$. 

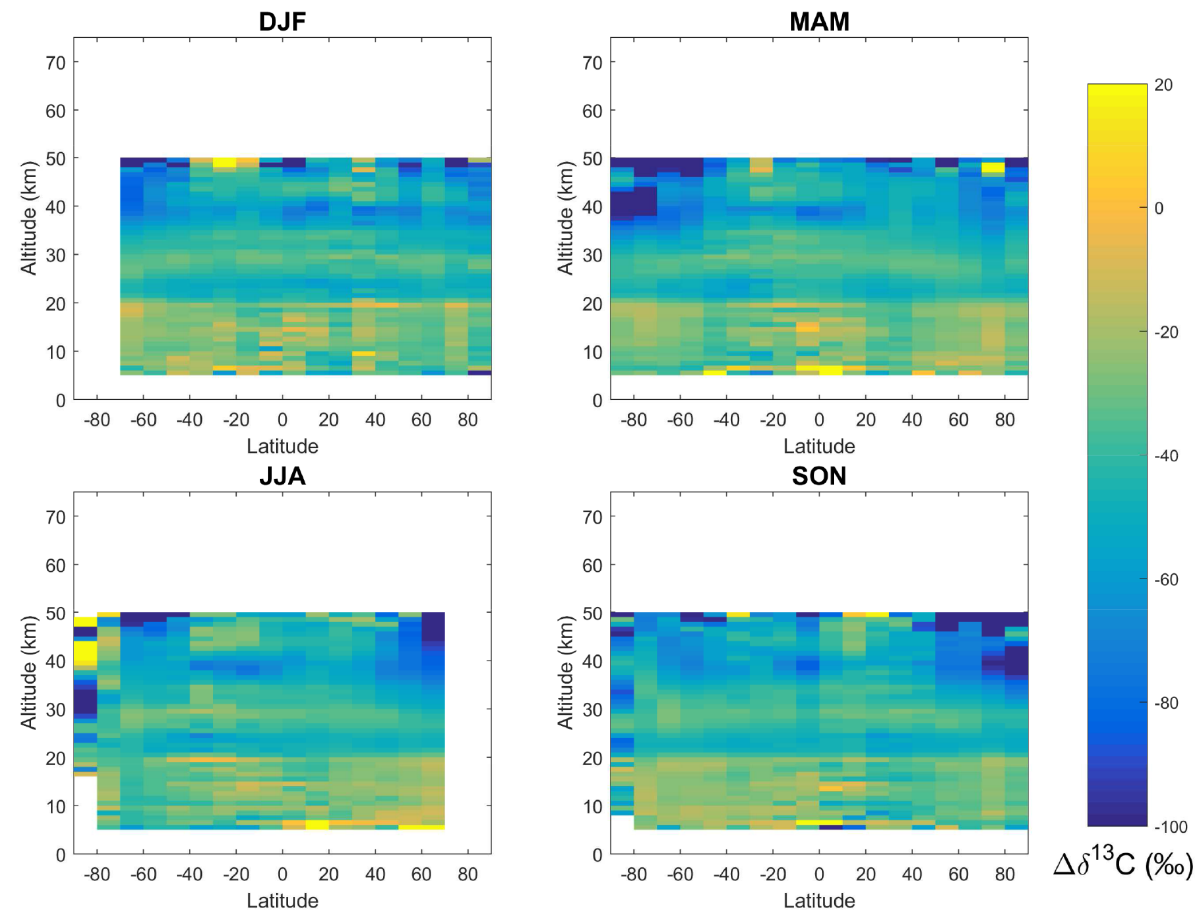

Figure 11. The difference in $\delta^{13} \mathrm{C}$ between ACE and WACCM. Negative values are given when ACE reports a larger value than WACCM.

The effect of this calibration at one location, the $60^{\circ} \mathrm{S}$ ACE latitude bin during the spring ( $\mathrm{SON}$ ), is shown in Fig. 12. Also shown here are error bars on the postcalibration ACE data. These error bars represent 1 standard deviation of measurements from the entire data set at that altitude and latitude bin. The calibration is effective for $\mathrm{CH}_{3} \mathrm{D}$ as ACE and WACCM now agree with each other up to $26 \mathrm{~km}$ where the sharp increase in $\delta \mathrm{D}$ is observed in ACE. However, this calibration does not function as well for ${ }^{13} \mathrm{CH}_{4}$. After the calibration, ACE and WACCM agree up to a height of about $20 \mathrm{~km}$, but the bump in the ACE results between 20 and $25 \mathrm{~km}$ (associated with the latitude-independent band in the $\delta^{13} \mathrm{C}$ plots near $22 \mathrm{~km}$ mentioned previously) yields significantly poorer agreement in that altitude range. The ACE results also show a stronger increase of $\delta^{13} \mathrm{C}$ with increasing altitude above $20 \mathrm{~km}$ compared to WACCM.

\subsection{Comparison to balloon profiles}

ACE data were compared with balloon profiles analyzed by Röckmann et al. (2011). This data set consists of 13 balloon profiles, all of which have data for $\delta^{13} \mathrm{C}$ and all but two have data for $\delta \mathrm{D}$. The balloon launches were performed at Hyderabad, India $\left(17.5^{\circ} \mathrm{N}, 78.60^{\circ} \mathrm{E}\right)$, Kiruna, Sweden $\left(67.9^{\circ} \mathrm{N}\right.$, $\left.21.10^{\circ} \mathrm{E}\right)$, Aire-sur-l'Adour, France $\left(43.70^{\circ} \mathrm{N},-0.30^{\circ} \mathrm{E}\right)$, and Gap, France $\left(44.44^{\circ} \mathrm{N}, 6.14^{\circ} \mathrm{E}\right)$. The balloon profiles from each location were compared to ACE profiles from the same season and the $10^{\circ}$ latitude bin the balloon launches are located in. Both locations in France were considered together since only one launch was performed at Gap.

Figure 13 shows the comparison of $\delta \mathrm{D}$ among $\mathrm{ACE}$ (shown in red), WACCM (gray and black), and the balloon profiles (blue). The profiles over India and both locations in France show strong agreement among all three data sets to above $25 \mathrm{~km}$. Over India, the balloon profiles end below $30 \mathrm{~km}$, so there are no data to compare to the highest altitudes of ACE where $\delta \mathrm{D}$ rapidly increases. Over France, the balloon profiles reach as high as $33 \mathrm{~km}$, slightly higher than ACE, but do not show the spike in $\delta \mathrm{D}$ present in ACE. This, along with the high amount of random error present in the retrieval at this altitude, supports the notion that the rapid increase in $\delta \mathrm{D}$ at the highest altitudes in the ACE results is a retrieval artifact. One profile, ASA9309, does show increased $\delta$ D at the single highest point, but this is not conclusive. However, the profiles over Sweden do not show such agreement. Above $20 \mathrm{~km}$, the balloon profiles show a large increase and noticeable month-to-month changes in $\delta \mathrm{D}$, whereas ACE shows a more gradual rise. The sharp increase is likely due to strong influence from the polar vortex during the 2 years of measurements. The ACE data are a combination of 10 years of profiles, so years of strong vortex influence are balanced by years with less influence. Also, the run of WACCM does not include any interannual variation, so the effect of an average polar vortex is expected.

Figure 14 shows the comparison of the three data sets for $\delta^{13} \mathrm{C}$. Quantitatively, agreement is generally poorer between ACE and the balloon profiles than was observed for 

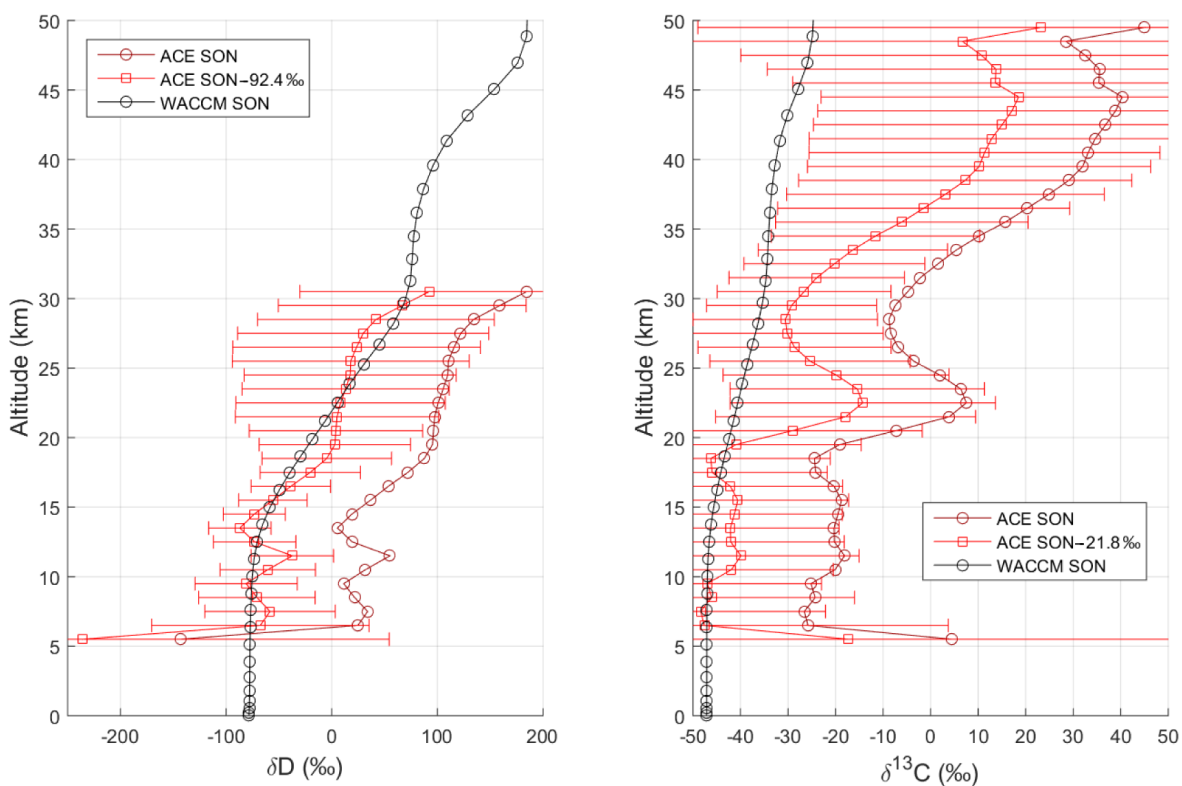

Figure 12. Results of ACE calibration compared to WACCM. Data shown here are from the $60^{\circ} \mathrm{S}$ September/October/November data bin. The error bars on the calibrated ACE data are equal to 1 standard deviation of the measurements at that altitude.
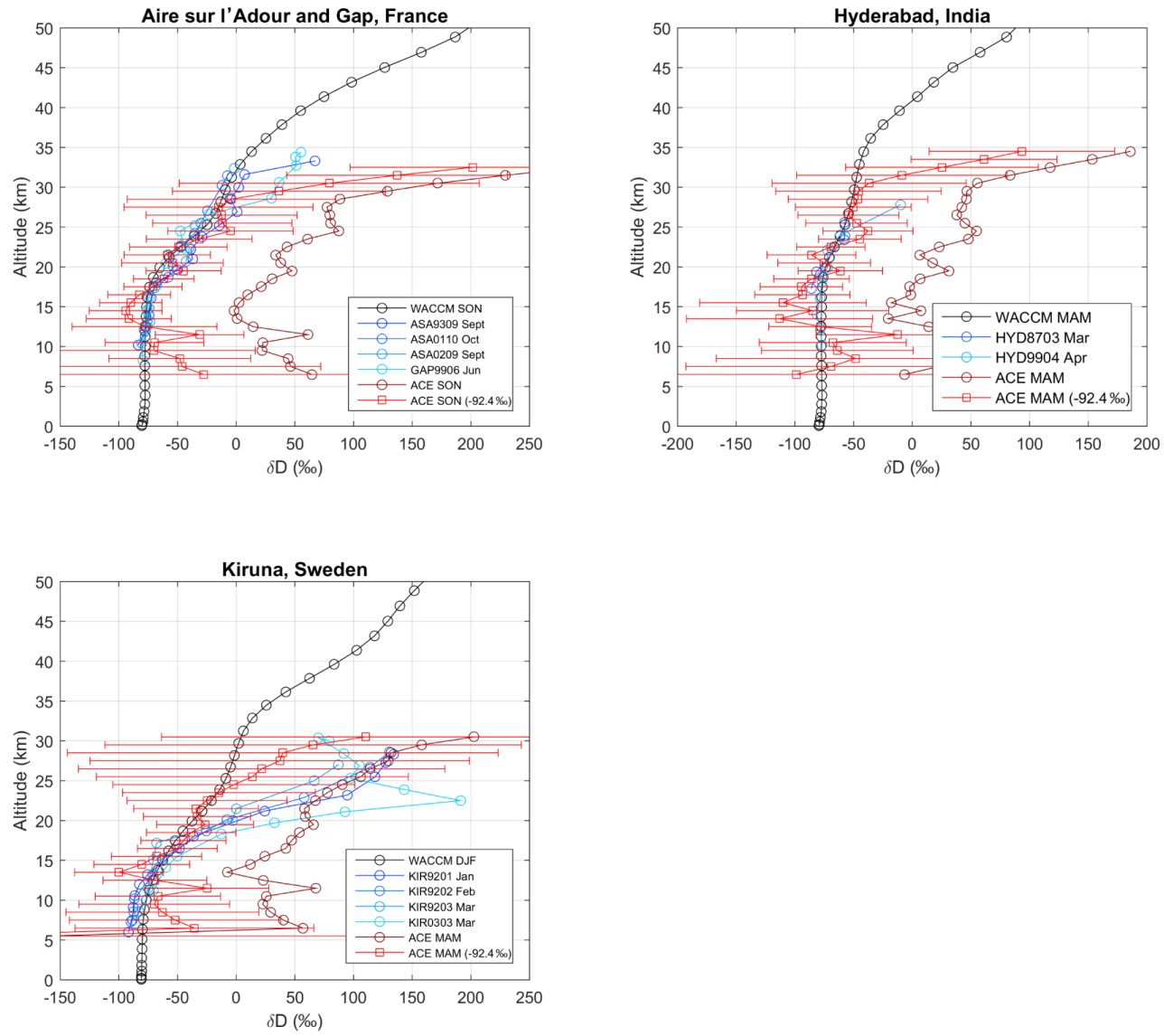

Figure 13. Comparison of $\delta$ D profiles from ACE before and after calibration, WACCM, and balloon profiles from Röckmann et al. (2011). 

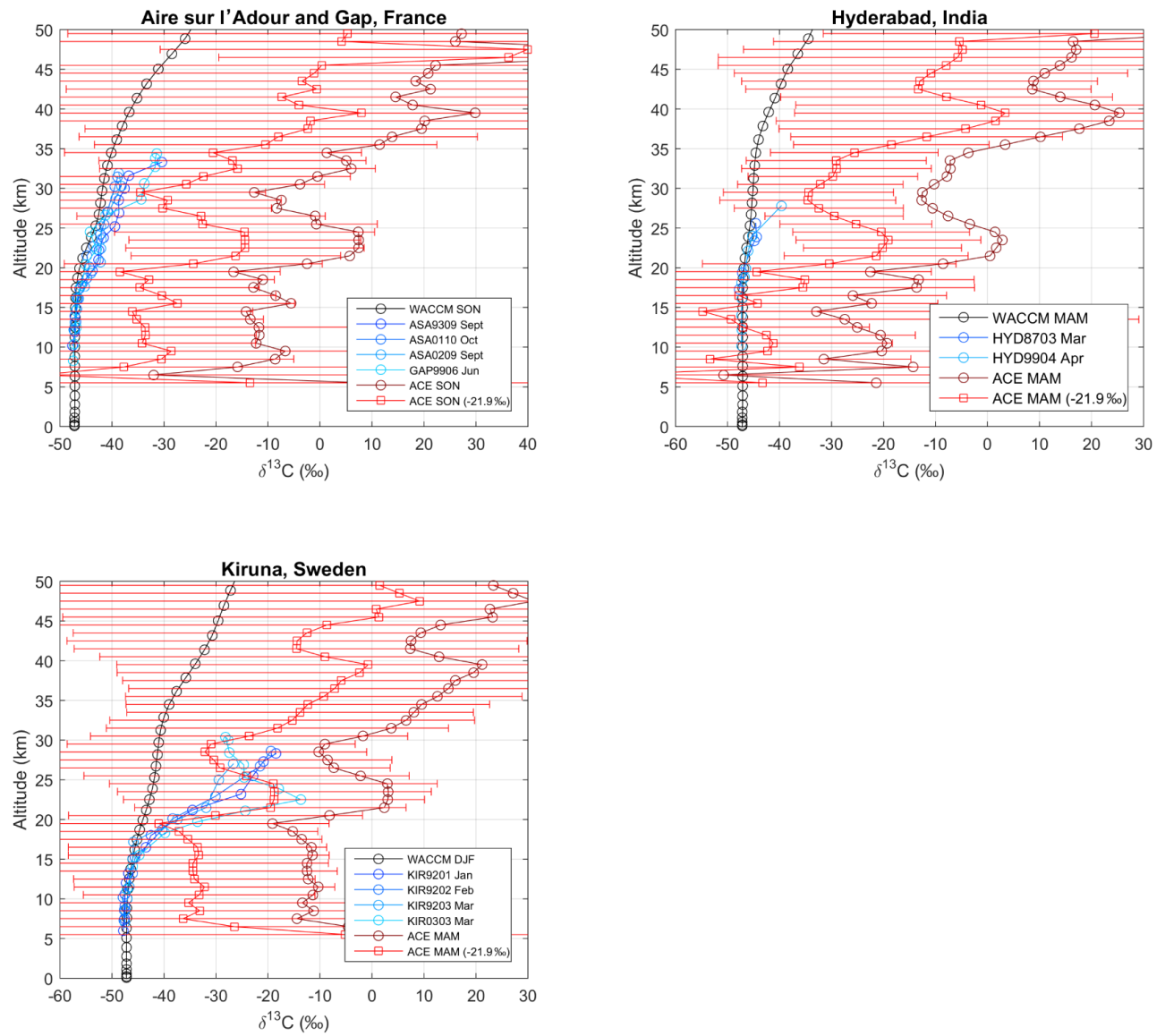

Figure 14. Comparison of $\delta^{13} \mathrm{C}$ profiles from ACE before and after calibration, WACCM, and balloon profiles from Röckmann et al. (2011).

$\delta$ D. Excluding the apparent artifact in the ACE $\delta^{13} \mathrm{C}$ results (the bump between 20 and $25 \mathrm{~km}$ ), there is reasonable agreement for the balloon measurements over India. For the higher-latitude measurements over France and Sweden, ACE indicates a smaller isotopic fractionation in the troposphere than was measured by the balloon campaign or predicted by WACCM. Interestingly, the balloon measurements in Sweden show fairly good agreement with the bump between 20 and $25 \mathrm{~km}$ in the $\mathrm{ACE} \delta^{13} \mathrm{C}$ results, but since this bump in the ACE results is thought to be an artifact, this agreement is probably a coincidence.

\subsection{Distribution of methane sinks}

A second set of WACCM runs was performed to further explore the effects of the different sinks of methane on its isotopic composition. The model was run an additional year past the initial 20 years. Then, several 1-day branch runs were performed on the first day of each month of the extra year. In these runs, the reactions for methane with $\mathrm{OH}, \mathrm{O}\left({ }^{1} \mathrm{D}\right)$, $\mathrm{Cl}$, and sunlight (photolysis) were modified to additionally produce an inert dummy molecule. The abundance of this "molecule" at a specific location shows how much methane reacted with a specific molecule or via photolysis at that location. Since the model reports molecular concentrations as mixing ratios, the abundance of the dummy molecules is relative to the number density of air at that location. The mixing ratios of the dummy molecules are on the order of $10^{-9}$ or smaller, so their presence does not have a large effect on the pressure or other dynamics in the atmosphere.

Figure 15 shows the results of these runs for the months of January, April, July, and October. The plots in the left column show which of the four sinks destroys the most methane at a given latitude and altitude. The right column shows the total rate of methane destruction. At the most abundant radical in the atmosphere, $\mathrm{OH}$ is the most important oxidant in the troposphere and most of the stratosphere outside of the polar regions. From 50 to $65 \mathrm{~km}$, singlet oxygen becomes the largest oxidant. It is also the largest oxidant between 30 and $40 \mathrm{~km}$ at the equator, likely due to the presence of the ozone layer below which readily photolyzes to give oxygen atoms. Above $65 \mathrm{~km}$, photolysis becomes the major source of methane destruction as the atmosphere becomes thinner, making chemical reactions more difficult and allowing the increased penetration of UV radiation. 

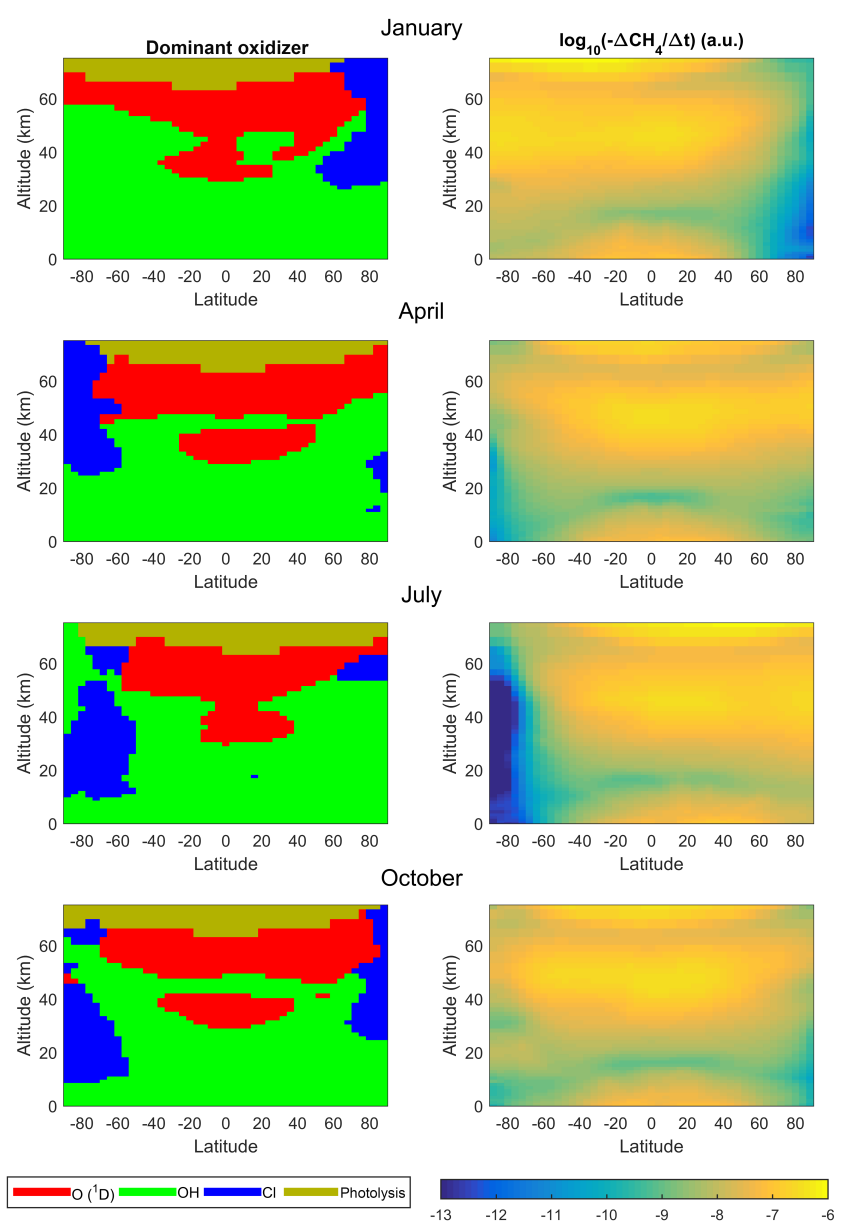

Figure 15. Dominant oxidizing species of $\mathrm{CH}_{4}$ by location and season (left) and total methane oxidation (right).

The reaction of methane with chlorine atoms demonstrates strong seasonal variation. Oxidation via chlorine is only major over the poles in the stratosphere around the winter months. At the same time over the poles, methane destruction reaches its lowest rates. This is due to the presence of the polar vortex. The isolated air inside the vortex is not exposed to sunlight, so oxidizing radicals are quickly consumed and are not regenerated. Meanwhile, active chlorine-containing compounds build up within the vortex, providing a small source of chlorine atoms even with minimal sunlight.

\section{Conclusions}

The ACE data set presented in this paper greatly expands the number of observations of methane and its isotopologues in the stratosphere. The data for $\mathrm{CH}_{3} \mathrm{D}$ have been shown to be consistent with both model predictions and existing balloonbased measurements after calibrating the ACE results using tropospheric $\delta \mathrm{D}$ calculated from the WACCM model. However, the data for ${ }^{13} \mathrm{CH}_{4}$ still show large discrepancies. The addition of new microwindows and adjustment of spectroscopic parameters for $\mathrm{CH}_{4}$ lines in the $2 v_{4}$ band significantly reduced the large step function observed in $\delta^{13} \mathrm{C}$ when using the spectroscopic parameters for this band that are currently available in the HITRAN database. However, a systematic latitude-independent bump near $22 \mathrm{~km}$ in the $\delta^{13} \mathrm{C}$ profiles derived from ACE in the current study suggests that further refinement of these spectroscopic constants will be required to improve the retrieval results for the isotopologues $\mathrm{CH}_{4}$ from ACE. 


\section{Appendix A}

The adjusted spectroscopic parameters generated for $\mathrm{CH}_{4}$ from ACE-FTS spectra are collected in the Supplement. Only those parameters that differ from the values in HITRAN 2004 are included. All units are the standard HITRAN units (Rothman et al., 2005). Spectroscopic parameters were adjusted primarily for the $\mathrm{CH}_{4}$ lines contained in the main isotopologue microwindow set. One adjustment made was an increase of the intensities in the low-altitude lines by more than $3 \%$. Not all $\mathrm{CH}_{4}$ in the given wave number region were adjusted, and no changes were made to the parameters for the subsidiary isotopologues.

It should be stressed that although these new parameters do significantly improve the fitting residuals and give volume mixing ratio profiles that yield variations with altitude that match more closely with expectations, an occultation sounder is not the ideal platform for generating spectroscopic parameters. Rather than a static cell, as one would have in a laboratory, there is a variation along the line of sight for pressure and temperature. Contribution to the residuals from imperfectly modeled interferences (i.e., molecules other than $\mathrm{CH}_{4}$ ) would impact the determination of $\mathrm{CH}_{4}$ spectroscopic parameters. The range of temperatures for the measurements is insufficient to properly generate spectroscopic parameters that describe temperature dependence, and so such parameters were all fixed to the values in HITRAN 2004.
It is clear that $\mathrm{CH}_{4}$ would benefit greatly from new laboratory studies, particularly in the $2650 \mathrm{~cm}^{-1}$ region for the main isotopologue. The sharp features at a particular altitude in the fractionation plots indicate that problems with the spectroscopic parameters are the dominant source of systematic error in this study. For all isotopologues, retrievals for $\mathrm{CH}_{4}$ in different altitude regions are derived from different spectroscopic bands, and inconsistencies in the spectroscopy for the different bands generate sharp "steps" in the retrieved profiles. Isotope studies are sensitive to these systematic steps, making such studies an excellent tool for evaluating the internal consistency of the spectroscopy for the isotopologues involved.

This study illustrated a significant problem with the internal consistency of spectroscopic constants in different bands of $\mathrm{CH}_{4}$. The new $\mathrm{CH}_{4}$ spectroscopic parameters reported here reduce that inconsistency, but problems remain. At this time, it is unclear whether the remaining systematic features in the fractionation plots arise primarily from the subsidiary isotopologues, from the main isotopologue, or some combination thereof. 


\section{The Supplement related to this article is available online at doi:10.5194/amt-9-1095-2016-supplement.}

Acknowledgements. The ACE mission is funded primarily by the Canadian Space Agency. This project was initiated during a visit by P. Bernath to the National Center of Atmospheric Research (NCAR) in Boulder, CO, and the help with WACCM provided by D. Kinnison, D. Marsh, and M. Mills is gratefully acknowledged. We thank T. Röckmann for supplying the methane isotopologue data from balloon measurements.

Edited by: F. Hase

\section{References}

Allan, W., Manning, M. R., Lassey, K. R., Lowe, D. C., and Gomez, A. J.: Modeling the variation of $\delta^{13} \mathrm{C}$ in atmospheric methane: Phase ellipses and the kinetic isotope effect, Global Biogeochem. Cy., 15, 467-481, doi:10.1029/2000GB001282, 2001.

Andrews, A. E., Kofler, J. D., Trudeau, M. E., Williams, J. C., Neff, D. H., Masarie, K. A., Chao, D. Y., Kitzis, D. R., Novelli, P. C., Zhao, C. L., Dlugokencky, E. J., Lang, P. M., Crotwell, M. J., Fischer, M. L., Parker, M. J., Lee, J. T., Baumann, D. D., Desai, A. R., Stanier, C. O., De Wekker, S. F. J., Wolfe, D. E., Munger, J. W., and Tans, P. P.: $\mathrm{CO}_{2}, \mathrm{CO}$, and $\mathrm{CH}_{4}$ measurements from tall towers in the NOAA Earth System Research Laboratory's Global Greenhouse Gas Reference Network: instrumentation, uncertainty analysis, and recommendations for future high-accuracy greenhouse gas monitoring efforts, Atmos. Meas. Tech., 7, 647-687, doi:10.5194/amt-7-647-2014, 2014.

Bartlett, K. B. and Harriss, R. C.: Review and assessment of methane emissions from wetlands, Chemosphere, 26, 261-320, doi:10.1016/0045-6535(93)90427-7, 1993.

Beale, C. A., Buzan, E. M., Boone, C. D., and Bernath, P. F.: Near-global distribution of $\mathrm{CO}$ isotopic fractionation in the Earth's atmosphere, J. Mol. Spectrosc., 1-8, doi:10.1016/j.jms.2015.12.005, 2015.

Boone, C. D., Nassar, R., Walker, K. A., Rochon, Y., McLeod, S. D., Rinsland, C. P., and Bernath, P. F.: Retrievals for the atmospheric chemistry experiment Fourier-transform spectrometer, Appl. Opt., 44, 7218, doi:10.1364/AO.44.007218, 2005.

Boone, C. D., Walker, K. A., and Bernath, P. F.: Version 3 Retrievals of the Atmospheric Chemistry Experiment Fourier Transform Spectrometer (ACE-FTS), in: The Atmospheric Chemistry Experiment: ACE at 10, edited by: Bernath, P. F., 103-129, A, Deepak Publishing, Hampton, VA, available at: http://www.ace. uwaterloo.ca/v1data/Boone-retrievals2005reprint.pdf (last access: 26 February 2016), 2013.

Brenninkmeijer, C. A. M., Crutzen, P., Boumard, F., Dauer, T., Dix, B., Ebinghaus, R., Filippi, D., Fischer, H., Franke, H., Frieß, U., Heintzenberg, J., Helleis, F., Hermann, M., Kock, H. H., Koeppel, C., Lelieveld, J., Leuenberger, M., Martinsson, B. G., Miemczyk, S., Moret, H. P., Nguyen, H. N., Nyfeler, P., Oram, D., O’Sullivan, D., Penkett, S., Platt, U., Pupek, M., Ramonet, M., Randa, B., Reichelt, M., Rhee, T. S., Rohwer, J., Rosenfeld, K.,
Scharffe, D., Schlager, H., Schumann, U., Slemr, F., Sprung, D., Stock, P., Thaler, R., Valentino, F., van Velthoven, P., Waibel, A., Wandel, A., Waschitschek, K., Wiedensohler, A., Xueref-Remy, I., Zahn, A., Zech, U., and Ziereis, H.: Civil Aircraft for the regular investigation of the atmosphere based on an instrumented container: The new CARIBIC system, Atmos. Chem. Phys., 7, 4953-4976, doi:10.5194/acp-7-4953-2007, 2007.

Conny, J. M. and Currie, L. A.: The isotopic characterization of methane, non-methane hydrocarbons and formaldehyde in the troposphere, Atmos. Environ., 30, 621-638, doi:10.1016/13522310(95)00305-3, 1996.

Denman, K. L., Brasseur, G., Chidthaisong, A., Ciais, P., Cox, P. M., Dickinson, R. E., Hauglustaine, D., Heinze, C., Holland, E., Jacob, D., Lohmann, U., Ramachandran, S., Dias, P. L. da S., Wofsy, S. C., and Zhang, X.: Couplings between changes in the climate system and biogeochemistry, in: Climate Change 2007: The Physical Science Basis. Contribution of Working Group I to the Fourth Assessment Report of the Intergovernmental Panel on Climate Change, edited by: Solomon, S., Qin, D., Manning, M., Chen, Z., Marquis, M., Averyt, K. B.,Tignor, M., and Miller, H. L., Cambridge University Press, Cambridge, UK, 499587, 2007.

Etheridge, D. M., Steele, L. P., Francey, R. J., and Langenfelds, R. L.: Atmospheric methane between 1000 A.D., and present: Evidence of anthropogenic emissions and climatic variability, J Geophys. Res., 103, 15979, doi:10.1029/98JD00923, 1998.

Feilberg, K. L., Griffith, D. W. T., Johnson, M. S., and Nielsen, C. J.: The ${ }^{13} \mathrm{C}$ and $\mathrm{D}$ kinetic isotope effects in the reaction of $\mathrm{CH}_{4}$ with Cl, Int. J. Chem. Kinet., 37, 110-118, doi:10.1002/kin.20058, 2005.

Hao, W. M. and Ward, D. E.: Methane production from global biomass burning, J. Geophys. Res., 98, 20657, doi:10.1029/93JD01908, 1993.

Keeling, C. D.: The concentration and isotopic abundances of atmospheric carbon dioxide in rural areas, Geochim. Cosmochim. Ac., 13, 322-334, doi:10.1016/0016-7037(58)90033-4, 1958.

Kort, E. A., Frankenberg, C., Costigan, K. R., Lindenmaier, R., Dubey, M. K., and Wunch, D.: Four corners: The largest US methane anomaly viewed from space, Geophys. Res. Lett., 41, 6898-6903, doi:10.1002/2014GL061503, 2014.

Lamarque, J.-F., Bond, T. C., Eyring, V., Granier, C., Heil, A., Klimont, Z., Lee, D., Liousse, C., Mieville, A., Owen, B., Schultz, M. G., Shindell, D., Smith, S. J., Stehfest, E., Van Aardenne, J., Cooper, O. R., Kainuma, M., Mahowald, N., McConnell, J. R., Naik, V., Riahi, K., and van Vuuren, D. P.: Historical (1850-2000) gridded anthropogenic and biomass burning emissions of reactive gases and aerosols: methodology and application, Atmos. Chem. Phys., 10, 7017-7039, doi:10.5194/acp10-7017-2010, 2010.

Lassey, K. R.: Livestock methane emission: From the individual grazing animal through national inventories to the global methane cycle, Agr. Forest Meteorol., 142, 120-132, doi:10.1016/j.agrformet.2006.03.028, 2007.

Lassey, K. R., Allan, W., and Fletcher, S. E. M.: Seasonal interrelationships in atmospheric methane and companion $\delta^{13} \mathrm{C}$ values: Effects of sinks and sources, Tellus, Ser. B Chem. Phys. Meteorol., 63, 287-301, doi:10.1111/j.1600-0889.2011.00535.x, 2011. 
Lee, A. Y. T., Yung, Y. L., Cheng, B.-M., Bahou, M., Chung, C.-Y., and Lee, Y.-P.: Enhancement of Deuterated Ethane on Jupiter, Astrophys. J., 551, L93-L96, doi:10.1086/319827, 2001.

Manney, G. L., Daffer, W. H., Zawodny, J. M., Bernath, P. F., Hoppel, K. W., Walker, K. A., Knosp, B. W., Boone, C., Remsberg, E. E., Santee, M. L., Harvey, V. L., Pawson, S., Jackson, D. R., Deaver, L., McElroy, C. T., McLinden, C. A., Drummond, J. R., Pumphrey, H. C., Lambert, A., Schwartz, M. J., Froidevaux, L., McLeod, S., Takacs, L. L., Suarez, M. J., Trepte, C. R., Cuddy, D. C., Livesey, N. J., Harwood, R. S., and Waters, J. W.: Solar occultation satellite data and derived meteorological products: Sampling issues and comparisons with Aura Microwave Limb Sounder, J. Geophys. Res., 112, D24S50, doi:10.1029/2007JD008709, 2007.

Marsh, D. R., Mills, M. J., Kinnison, D. E., Lamarque, J.-F., Calvo, N., and Polvani, L. M.: Climate Change from 1850 to 2005 Simulated in CESM1(WACCM), J. Clim., 26, 7372-7391, doi:10.1175/JCLI-D-12-00558.1, 2013.

Nair, H., Summers, M., Miller, C., and Yung, Y.: Isotopic fractionation of methane in the martian atmosphere, Icarus, 175, 32-35, doi:10.1016/j.icarus.2004.10.018, 2005.

Park, M.: Seasonal variation of methane, water vapor, and nitrogen oxides near the tropopause: Satellite observations and model simulations, J. Geophys. Res., 109, D03302, doi:10.1029/2003JD003706, 2004.

Payan, S., Camy-Peyret, C., Oelhaf, H., Wetzel, G., Maucher, G., Keim, C., Pirre, M., Huret, N., Engel, A., Volk, M. C., Kuellmann, H., Kuttippurath, J., Cortesi, U., Bianchini, G., Mencaraglia, F., Raspollini, P., Redaelli, G., Vigouroux, C., De Mazière, M., Mikuteit, S., Blumenstock, T., Velazco, V., Notholt, J., Mahieu, E., Duchatelet, P., Smale, D., Wood, S., Jones, N., Piccolo, C., Payne, V., Bracher, A., Glatthor, N., Stiller, G., Grunow, K., Jeseck, P., Te, Y., and Butz, A.: Validation of version-4.61 methane and nitrous oxide observed by MIPAS, Atmos. Chem. Phys., 9, 413-442, doi:10.5194/acp-9-413-2009, 2009.

Remsberg, E. E.: Methane as a diagnostic tracer of changes in the Brewer-Dobson circulation of the stratosphere, Atmos. Chem. Phys., 15, 3739-3754, doi:10.5194/acp-15-3739-2015, 2015.

Rice, A. L., Tyler, S. C., McCarthy, M. C., Boering, K. A., and Atlas, A.: Carbon and hydrogen isotopic compositions of stratospheric methane: 1. High-precision observations from the NASA ER-2 aircraft, J. Geophys. Res., 108, 4460, doi:10.1029/2002JD003042, 2003.

Röckmann, T., Brass, M., Borchers, R., and Engel, A.: The isotopic composition of methane in the stratosphere: high-altitude balloon sample measurements, Atmos. Chem. Phys., 11, 13287-13304, doi:10.5194/acp-11-13287-2011, 2011.

Rothman, L. S., Jacquemart, D., Barbe, A., Chris Benner, D., Birk, M., Brown, L. R., Carleer, M. R., Chackerian, C., Chance, K., Coudert, L. H., Dana, V., Devi, V. M., Flaud, J.-M., Gamache, R. R., Goldman, A., Hartmann, J.-M., Jucks, K. W., Maki, A. G., Mandin, J.-Y., Massie, S. T., Orphal, J., Perrin, A., Rinsland, C. P., Smith, M. A. H., Tennyson, J., Tolchenov, R. N., Toth, R. A., Vander Auwera, J., Varanasi, P., and Wagner, G.: The HITRAN 2004 molecular spectroscopic database, J. Quant. Spectrosc. Ra., 96, 139-204, doi:10.1016/j.jqsrt.2004.10.008, 2005.

Rothman, L. S., Gordon, I. E., Barbe, A., Benner, D. C., Bernath, P. F., Birk, M., Boudon, V., Brown, L. R., Campargue, A., Champion, J.-P., Chance, K., Coudert, L. H., Dana, V., Devi,
V. M., Fally, S., Flaud, J.-M., Gamache, R. R., Goldman, A., Jacquemart, D., Kleiner, I., Lacome, N., Lafferty, W. J., Mandin, J.-Y., Massie, S. T., Mikhailenko, S. N., Miller, C. E., Moazzen-Ahmadi, N., Naumenko, O. V., Nikitin, A. V., Orphal, J., Perevalov, V. I., Perrin, A., Predoi-Cross, A., Rinsland, C. P., Rotger, M., Šimečková, M., Smith, M. A. H., Sung, K., Tashkun, S. A., Tennyson, J., Toth, R. A., Vandaele, A. C., and Vander Auwera, J.: The HITRAN 2008 molecular spectroscopic database, J. Quant. Spectrosc. Ra., 110, 533-572, doi:10.1016/j.jqsrt.2009.02.013, 2009.

Sander, S. P., Friedl, R. R., Golden, D. M., Kurylo, M. J., Moortgat, G. K., Wine, P. H., Ravishankara, a R., Kolb, C. E., Molina, M. J., Diego, S., Jolla, L., Huie, R. E., and Orkin, V. L.: Chemical Kinetics and Photochemical Data for Use in Atmospheric Studies Evaluation Number 15, JPL Publ., 06-2(Eval. 15), available at: http://jpldataeval.jpl.nasa.gov/ (last access: 26 February 2016), 2006.

Saueressig, G., Crowley, J. N., Bergamaschi, P., Brühl, C., Brenninkmeijer, C. A. M., and Fischer, H.: Carbon 13 and D kinetic isotope effects in the reactions of $\mathrm{CH}_{4}$ with $\mathrm{O}(1 \mathrm{D})$ and $\mathrm{OH}$ : New laboratory measurements and their implications for the isotopic composition of stratospheric methane, J. Geophys. Res., 106, 23127, doi:10.1029/2000JD000120, 2001.

Schneising, O., Buchwitz, M., Burrows, J. P., Bovensmann, H., Bergamaschi, P., and Peters, W.: Three years of greenhouse gas column-averaged dry air mole fractions retrieved from satellite - Part 2: Methane, Atmos. Chem. Phys., 9, 443-465, doi:10.5194/acp-9-443-2009, 2009.

Sugawara, S., Nakazawa, T., Shirakawa, Y., Kawamura, K., Aoki, S., Machida, T., and Honda, H.: Vertical profile of the carbon isotopic ratio of stratospheric methane over Japan, Geophys. Res. Lett., 24, 2989-2992, doi:10.1029/97GL03044, 1997.

Terao, Y., Mukai, H., Nojiri, Y., MacHida, T., Tohjima, Y., Saeki, T., and Maksyutov, S.: Interannual variability and trends in atmospheric methane over the western Pacific from 1994 to 2010, J. Geophys. Res.-Atmos., 116, 1-13, doi:10.1029/2010JD015467, 2011.

Umezawa, T., Machida, T., Ishijima, K., Matsueda, H., Sawa, Y., Patra, P. K., Aoki, S., and Nakazawa, T.: Carbon and hydrogen isotopic ratios of atmospheric methane in the upper troposphere over the Western Pacific, Atmos. Chem. Phys., 12, 8095-8113, doi:10.5194/acp-12-8095-2012, 2012.

Wecht, K. J., Jacob, D. J., Wofsy, S. C., Kort, E. A., Worden, J. R., Kulawik, S. S., Henze, D. K., Kopacz, M., and Payne, V. H.: Validation of TES methane with HIPPO aircraft observations: implications for inverse modeling of methane sources, Atmos. Chem. Phys., 12, 1823-1832, doi:10.5194/acp-12-1823-2012, 2012.

Xiong, X., Barnet, C., Maddy, E. S., Gambacorta, A., King, T. S., and Wofsy, S. C.: Mid-upper tropospheric methane retrieval from IASI and its validation, Atmos. Meas. Tech., 6, 2255-2265, doi:10.5194/amt-6-2255-2013, 2013.

Yokota, T., Yoshida, Y., Eguchi, N., Ota, Y., Tanaka, T., Watanabe, H., and Maksyutov, S.: Global Concentrations of $\mathrm{CO}_{2}$ and $\mathrm{CH}_{4}$ Retrieved from GOSAT: First Preliminary Results, Sci. Online Lett. Atmos., 5, 160-163, doi:10.2151/sola.2009-041, 2009. 